\title{
Semiconductor thin films by chemical bath deposition for solar energy related applications
}

\author{
P.K. Nair*, M.T.S. Nair, V.M. García, O.L. Arenas, Y. Peña, \\ A. Castillo, I.T. Ayala, O. Gomezdaza, A. Sánchez, J. Campos, \\ H. Hu, R. Suárez, M.E. Rincón
}

Department of Solar Energy Materials, Centro de Investigación en Energía, Universidad Nacional Autonoma de México, Temixco, Morelos 62580, Mexico

Received 1 October 1996; received in revised form 20 May 1997

\begin{abstract}
In this paper we present the basic concepts underlying the chemical bath deposition technique and the recipes developed in our laboratory during the past ten years for the deposition of good-quality thin films of $\mathrm{CdS}, \mathrm{CdSe}, \mathrm{ZnS}, \mathrm{ZnSe}, \mathrm{PbS}, \mathrm{SnS}, \mathrm{Bi}_{2} \mathrm{~S}_{3}, \mathrm{Bi}_{2} \mathrm{Se}_{3}, \mathrm{Sb}_{2} \mathrm{~S}_{3}$, $\mathrm{CuS}, \mathrm{CuSe}$, etc. Typical growth curves, and optical and electrical properties of these films are presented. The effect of annealing the films in air on their structure and composition and on the electrical properties is notable: $\mathrm{CdS}$ and $\mathrm{ZnS}$ films become conductive through a partial conversion to oxide phase; CdSe becomes photosensitive, $\mathrm{SnS}$ converts to $\mathrm{SnO}_{2}$, etc. The use of precipitates formed during deposition for screen printing and sintering, in polymer composites and as a source for vapor-phase deposition is presented. Some examples of the application of the films in solar energy related work are presented. (C) 1998 Elsevier Science B.V. All rights reserved.
\end{abstract}

Keywords: Thin films; Growth curves; Optical and electrical properties

\section{Introduction}

Chemical bath deposition technique is well suited for producing large-area thin films for solar energy related applications. In this paper we would share our

* Corresponding author. 
experience in this technique, acquired at the Laboratorio de Energia Solar (presently Centro de Investigación en Energía) during the past $10 \mathrm{yr}$, with researchers in this field and others who would be interested to initiate work in this research area.

Chemical bath deposition is a technique in which thin semiconductor films are deposited on substrates immersed in dilute solutions containing metal ions and a source of hydroxide, sulfide or selenide ions. The earliest reported work dates back to 1919 and dealt with the deposition of $\mathrm{PbS}$ thin films [1]. The basic principles underlying the chemical bath deposition of semiconductor thin films and early research work in this area have been presented in a 1982 review article [2], which has inspired many researchers to initiate work in this area. The subsequent progress in this area is contained in a 1991 review article [3], which lists literature on more than 35 compounds prepared by this technique and related references. Recipes for the chemical bath deposition of a number of such compounds are given in a recent paper [4]. The number of possible materials to be produced through the technique is bound to multiply in subsequent years. This is due to the feasibility of producing multilayer films by this technique - the annealing of which promotes interfacial diffusion of metal ions and the production of new materials with improved thermal stabilities. For example, interfacial diffusions in chemically deposited $\mathrm{PbS}-\mathrm{CuS}$ and $\mathrm{ZnS}-\mathrm{CuS}$ coatings result in materials such as $\mathrm{Pb}_{x} \mathrm{Cu}_{y} \mathrm{~S}_{z}$ and $\mathrm{Zn}_{x} \mathrm{Cu}_{y} \mathrm{~S}_{z}$ with p-type conductivities and are stable up to a temperature of $300^{\circ} \mathrm{C}$ [5]. Annealing of $\mathrm{Bi}_{2} \mathrm{~S}_{3}$ (bismuthinite)-CuS (covellite) coating at temperatures of $250-300^{\circ} \mathrm{C}$ leads to the formation of a new compound, $\mathrm{Cu}_{3} \mathrm{BiS}_{3}$ (wittichenite), with p-type conductivity [6].

Among the first applications of chemically deposited semiconductor thin films, we find $\mathrm{PbS}$ and $\mathrm{PbSe}$ photodetectors [7]. Even though chemically deposited CdS films were developed during 1960s, the photodetector applications of CdS were confined to screen-printed and sintered layers [8]. However, chemically deposited CdSe thin films were found appropriate for photodetector applications [9]. In the late 1970s and early 1980s the motivation in the work on chemically deposited thin films has been their prospective solar energy applications. One of the earlier developments toward this was in solar absorber coatings [10], followed by specific application of such coatings in evacuated all-glass tubular collectors [11]. Application of the chemically deposited films in solar control coatings was suggested in 1989 [12]. Subsequently the performance evaluation of such coatings was reported [13].

The use of chemically deposited semiconductor films to develop photoelectrochemical solar cells was of basic interest, most importantly, in the case of CdS and CdSe thin films $[2,14,15]$. Recent work on chemically deposited CdSe and $\mathrm{Sb}_{2} \mathrm{~S}_{3}$ films with an incorporated $\mathrm{WO}_{3}$ component has shown improved conversion efficiencies and stabilities in photoelectrochemical solar cell configuration [16].

The integration of chemically deposited semiconductor thin films in thin-film solar cell has only a short history. In 1990, a thin layer of chemically deposited CdS thin film was integrated into a structure $\mathrm{Mo}-\mathrm{CuInSe} \mathrm{I}_{2}-\mathrm{CdS}-\mathrm{ZnO}$ producing approximately $11 \%$ of conversion efficiency [17]. This was followed by improved cell design resulting in record efficiencies of $>17 \%$ [18], in which the chemically deposited CdS film of $\sim 0.05 \mu \mathrm{m}$ continued to play the role of an inevitable component. The incorporation of highly resistive $\mathrm{CdS}$ film in the solar cell structure, (p)CuInSe ${ }_{2}-\mathrm{CdS}-(\mathrm{n}) \mathrm{CdS}$, was 
identified in 1979-80 as an essential step towards improving the solar cell stability [19]. Theoretical calculations done in 1982 [20] predicted that the thickness of the CdS film should be as small as possible to increase the cell efficiency. The chemical deposition technique, which excels in providing complete surface coverage at very small film thicknesses was therefore chosen to produce this very thin film with excellent success [21].

The use of chemically deposited n-CdSe or $\mathrm{n}-\mathrm{Sb}_{2} \mathrm{~S}_{3}$ films with incorporated $\mathrm{WO}_{3}$ phase as an active absorber material in Schottky barrier solar cells has been proven factible. For example, $V_{\mathrm{oc}}$ of $0.72 \mathrm{~V} ; I_{\mathrm{sc}}$ of $14.1 \mathrm{~mA} \mathrm{~cm}^{-2}$; FF of 0.7 and conversion efficiency of $5.5 \%$ have been demonstrated in ITO-(n)CdSe $(5 \mu \mathrm{m})-\mathrm{Pt} / \mathrm{Ni} / \mathrm{Au}(130 \AA)$ Schottky cells $[16,22,23]$. Similarly, the fabrication of heterojunction solar cells using chemically deposited $\mathrm{Sb}_{2} \mathrm{~S}_{3}$ thin films on (p)Si/(p)Ge/(p)InP wafers has been demonstrated $[16,22,24]$.

The photoaccelerated chemical deposition on $\mathrm{PbS}$ thin films was reported in 1991 [25] in which the illuminated region in a growing thin film showed accelerated deposition. The application of this effect in producing images in PbS thin film [26] and $\mathrm{Bi}_{2} \mathrm{~S}_{3}$ thin film [27] has been reported. The potential use of the photoacceleration effect in attaining high deposition rate is evident.

The above range of prospective applications, particularly, in the area of solar energy conversion and energy efficiency has prompted renewed interest in chemically deposited semiconductor thin films. The technique is ideally suited for the production of large area thin films as required for solar energy applications. In this paper we shall outline the technique for the preparation of a number of chemically deposited semiconductor thin films. The importance of post-deposition treatment in the modification of chemically deposited thin films for various applications and the prospects for producing new solar energy materials through interfacial diffusion of metal ions will be discussed. The use of the precipitate produced in the deposition bath during thinfilm deposition, for the production of semiconductor coatings by other deposition techniques will also be presented.

\section{Experimental}

\subsection{Chemical bath deposition}

The basic advantages of chemical bath deposition have been highlighted by various authors $[1-4,16]$. The technique is applicable for the deposition of highly insoluble compounds. For example, the solubility of $\mathrm{CuS}$ at room temperature in water is estimated to be $10^{-36} \mathrm{~g} \mathrm{dm}^{-3}$, or in other words, the product of the ionic concentrations of the $\mathrm{Cu}^{2+}$ and the $\mathrm{S}^{2-}$ ions in the saturated aqueous solution of $\mathrm{CuS}$ is $10^{-36} \mathrm{~mol}^{2} \mathrm{dm}^{-6}$. This is the solubility product (SP). If in an arbitrarily constituted aqueous solution of $\mathrm{Cu}^{2+}$ and $\mathrm{S}^{2-}$ ions, the product of their ionic concentration (IP) is $>10^{-36} \mathrm{~mol}^{2} \mathrm{dm}^{-6}$, the excess ions will be precipitated as CuS. The details of these concepts are given in standard sources [28]. A list of the solubility products of sulfides and hydroxides of various metals is given in Ref. [29]. 
In the above-mentioned event, if the precipitation is controlled through the use of suitable complexing agents such as triethanolamine for the metal ions (so as to reduce the amount of free metal ions [30]) and the amount of sulfide, selenide, or hydroxo ions in the bath is controlled through setting up of appropriate chemical equilibria $[2,3]$, thin-film deposition can take place. A further condition to be satisfied is the availability of nucleation centers over the substrate. Such centers are normally formed through the adsorption of metal hydroxo species over the surface. The hydroxo group would be substituted by the sulfide or selenide ions which would thereby form an initial layer of the metal chalcogenide [31]. The deposition of the thin film takes place through the condensation of the metal and sulfide/selenide ions on this initial layer, which acts as a catalytic surface.

The following compositions for the chemical deposition baths have been developed in our laboratory over many years. They have been tested for their reproducibility and have been found to be very reliable for the deposition of thin films in the thickness range $0.05-0.5 \mu \mathrm{m}$. The given volumes of the constituents are the quantities required to prepare $100 \mathrm{ml}$ of the deposition bath. The usual substrates are microscope glass slides, $75 \mathrm{~mm} \times 25 \mathrm{~mm} \times 1 \mathrm{~mm}$, cleaned in a detergent solution and rinsed well in running tap water. These are mounted nearly vertical on the wall of a $100 \mathrm{ml}$ beaker containing the bath. Up to six substrates may be placed in a $100 \mathrm{ml}$ beaker in this way. Deposition on a large-area commercial sheet glass may be made by slowly laying them down on a shallow tray containing the deposition bath. The sheet glass would be separated from the bottom of the tray by spacers in such a way that an approximately $5 \mathrm{~mm}$ thick layer of deposition bath separates the bottom surface of the sheet glass and the bottom of the tray. The thin-film deposition would take place at the bottom surface of the sheet glass. Coatings on sheet glass of $60 \mathrm{~cm} \times 60 \mathrm{~cm}$ are routinely made in our laboratory by this technique using approximately $2000 \mathrm{ml}$ each of the deposition bath. Relatively low-cost reagents, of purity not more than $98 \%$, are usually sufficient for the preparation of the deposition baths.

CdS thin film [32]: $30 \mathrm{ml}$ of $0.1 \mathrm{M} \mathrm{Cd}\left(\mathrm{CH}_{3} \mathrm{COO}\right)_{2} \cdot 2 \mathrm{H}_{2} \mathrm{O}, 8-12 \mathrm{ml}$ of $1 \mathrm{M}$ sodium citrate, $15 \mathrm{ml}$ of $1.5 \mathrm{M} \mathrm{NH}_{4} \mathrm{OH}, 5-10 \mathrm{ml}$ of $1 \mathrm{M}$ thiourea, and the rest deionized water to make the volume up to $100 \mathrm{ml}$. The deposition is allowed to proceed at $50-70^{\circ} \mathrm{C}$ for up to $12 \mathrm{~h}$. Very smooth and uniform coatings of $\mathrm{CdS}$ are formed except at long durations of deposition.

CdSe thin films [33,34]: $30 \mathrm{ml}$ of $0.1 \mathrm{M} \mathrm{Cd}\left(\mathrm{NO}_{3}\right)_{2} \cdot 4 \mathrm{H}_{2} \mathrm{O}, 12 \mathrm{ml}$ of $1 \mathrm{M}$ sodium citrate, $1.2 \mathrm{ml}$ of $30 \%(\sim 15 \mathrm{M}) \mathrm{NH}_{4} \mathrm{OH}, 0.4 \mathrm{~g}$ of N,N-dimethylselenourea dissolved in $30 \mathrm{ml}$ of freshly prepared $0.01 \mathrm{M} \mathrm{Na}_{2} \mathrm{SO}_{3}$, and the volume made up to $100 \mathrm{ml}$ with water. Depositions may be made at room temperature $(24 \mathrm{~h})$ or at temperatures up to $60^{\circ} \mathrm{C}(8 \mathrm{~h})$; at prolonged deposition there is risk of the film peeling from the glass substrates.

$\mathrm{ZnS}$ thin films [35]: $5 \mathrm{ml}$ of $1 \mathrm{M}$ zinc sulfate, $4.4 \mathrm{ml}$ of $\mathrm{NH}_{3} / \mathrm{NH}_{4} \mathrm{Cl}$ ( $\left.\mathrm{pH} 10\right), 5.4 \mathrm{ml}$ of $50 \%$ triethanolamine, $2 \mathrm{ml}$ of $1 \mathrm{M}$ thioacetamide, and the rest deionized water to make up to $100 \mathrm{ml}$ by volume. Depositions are made at $50^{\circ} \mathrm{C}$ for about $6 \mathrm{~h}$ or at room temperature for about $20 \mathrm{~h}$ to obtain $\mathrm{ZnS}$ films of $0.2 \mu \mathrm{m}$ thickness.

ZnSe thin films [36]: $35 \mathrm{ml}$ of $0.1 \mathrm{M}$ zinc acetate, $16 \mathrm{ml}$ of $0.8 \mathrm{M}$ sodium citrate, $5 \mathrm{ml}$ of $7.4 \mathrm{M}$ ammonium hydroxide, and $20 \mathrm{ml}$ of $0.07 \mathrm{M} \mathrm{N}, \mathrm{N}$-dimethylselenourea, and 
the volume made up to $100 \mathrm{ml}$ with deionized water. Depositions may be made at room temperature or in an oven at temperatures up to $60^{\circ} \mathrm{C}$.

SnS thin films [37]: $1 \mathrm{~g} \mathrm{SnCl}_{2} \cdot 2 \mathrm{H}_{2} \mathrm{O}$ dissolved in $5 \mathrm{ml}$ of acetone, $12 \mathrm{ml}$ of $50 \%$ triethanolamine, $8 \mathrm{ml}$ of $1 \mathrm{M}$ thioacetamide, $10 \mathrm{ml}$ of $4 \mathrm{M} \mathrm{NH}_{4} \mathrm{OH}$ and the rest water to make up the volume to $100 \mathrm{ml}$. The depositions may be made at temperatures up to $80^{\circ} \mathrm{C}$ to obtain thin films of thickness $0.7 \mu \mathrm{m}$.

PbS thin films [38]: $5 \mathrm{ml}$ of $1 \mathrm{M} \mathrm{Pb}\left(\mathrm{CH}_{3} \mathrm{COO}\right)_{2} \cdot 3 \mathrm{H}_{2} \mathrm{O}, 20 \mathrm{ml}$ of $1 \mathrm{M} \mathrm{NaOH}, 5 \mathrm{ml}$ of $1 \mathrm{M}$ thiourea, $5 \mathrm{ml}$ of $1 \mathrm{M}$ triethanolamine, and the rest water. The quality of films is best when depositions are done at room temperature.

$\mathrm{Bi}_{2} \mathrm{~S}_{3}$ thin films [39,40]: $10 \mathrm{ml}$ of $\simeq 0.5 \mathrm{M} \mathrm{Bi}\left(\mathrm{NO}_{3}\right)_{3} \cdot 5 \mathrm{H}_{2} \mathrm{O}$ solution, $8 \mathrm{ml}$ of $50 \%$ triethanol-amine, $4 \mathrm{ml}$ of $1 \mathrm{M}$ thioacetamide, and the rest water. The depositions are made at room temperature; there is risk of peeling of the film from the substrate at intermediate durations $(5-7 \mathrm{~h})$, but are seen to be adherent when the films are allowed to remain in the bath for more than $24 \mathrm{~h}$. Improved adhesion of the films are possible when the films are deposited over a substrate layer of $\mathrm{ZnS}$ [35].

$\mathrm{Bi}_{2} \mathrm{Se}_{3}$ thin films [41]: $7 \mathrm{ml}$ of $0.5 \mathrm{M} \mathrm{Bi}\left(\mathrm{NO}_{3}\right)_{3}$ solution, $7 \mathrm{ml}$ of $50 \%$ triethanolamine, $20 \mathrm{ml}$ of $0.07 \mathrm{M} \mathrm{N}, \mathrm{N}$-dimethylselenourea solution prepared freshly in $0.01 \mathrm{M} \mathrm{Na}_{2} \mathrm{SO}_{3}$, and the rest water. Films of $0.2 \mu \mathrm{m}$ may be deposited in about $9 \mathrm{~h}$ at $40^{\circ} \mathrm{C}$ or in about $60 \mathrm{~h}$ at room temperature. The films adhere well to glass substrates.

CuS thin films [42]: $5 \mathrm{ml}$ of $1 \mathrm{M} \mathrm{CuCl}_{2} \cdot 3 \mathrm{H}_{2} \mathrm{O}, 4 \mathrm{ml}$ triethanolamine, $8 \mathrm{ml}$ of $30 \%$ $\mathrm{NH}_{4} \mathrm{OH}, 10 \mathrm{ml}$ of $\simeq 1 \mathrm{M} \mathrm{NaOH}, 6 \mathrm{ml}$ of $1 \mathrm{M}$ thiourea, and the rest water. Depositions are made at room temperature for best results; the films peel from glass substrates during prolonged deposition, but it may be prevented by using a $\mathrm{ZnS}$ substrate film [35].

$\mathrm{Cu}_{2-x} \mathrm{Se}$ thin films: $10 \mathrm{ml}$ of $0.5 \mathrm{M} \mathrm{CuSO}_{4} \cdot 5 \mathrm{H}_{2} \mathrm{O}$ solution, $1.5 \mathrm{ml}$ of $30 \%$ $\mathrm{NH}_{4} \mathrm{OH}, 12 \mathrm{ml}$ of $\simeq 0.4 \mathrm{M} \mathrm{Na}_{2} \mathrm{SeSO}_{3}$ solution (prepared by reflexing $4 \mathrm{~g}$ of selenium powder in $100 \mathrm{ml}$ of $1 \mathrm{M} \mathrm{Na}_{2} \mathrm{SO}_{3}$ solution for about $3 \mathrm{~h}$ ), and the rest water. At room temperature, films of approx. $0.2 \mu \mathrm{m}$ thickness are deposited in $7 \mathrm{~h}$. The value of $x$ may depend on the exact bath composition and may even gradually change with the duration of deposition.

$\mathrm{Sb}_{2} \mathrm{~S}_{3}$ thin films: $0.65 \mathrm{~g} \mathrm{SbCl}_{3}$ dissolved in $2.5 \mathrm{ml}$ of acetone, $25 \mathrm{ml}$ of $1 \mathrm{M}$ sodium thiosulfate, and the rest water to make up the volume to $100 \mathrm{ml}$. The depositions were done at $10^{\circ} \mathrm{C}$ in a refrigerator.

The compositions of deposition baths for many other compound semiconductor thin films developed in other laboratories are summarized in Ref. [3].

\subsection{Characterization}

The X-ray diffraction patterns of the films were recorded on a Seimens D500 machine. The optical transmittance and the near-normal specular reflectance spectra of the samples were recorded on a Shimadzu 3101 PC UV VIS NIR spectrophotometer. For the electrical measurements, a pair of silver paint electrodes of $5 \mathrm{~mm}$ length at $5 \mathrm{~mm}$ separation were printed on the film surface to serve as contacts. The measurements were done using a computerized data acquisition system. 


\section{Results and discussion}

\subsection{Growth of thin films}

In general, the growth of good-quality semiconductor thin films by the chemical bath deposition technique proceeds at a slow pace. The technique is ideally suited for producing uniform films with thickness in the $0.05-0.3 \mu \mathrm{m}$ range in most cases. Film thickness up to a micron is possible in some cases. Thickness up to a few micron in chemically deposited $\mathrm{CdSe}$ and $\mathrm{Sb}_{2} \mathrm{~S}_{3}$ thin films have been reported from other laboratories [16]. Higher deposition rates and higher film thicknesses are usually accompanied by powdery deposits and a lack of specular reflection. Fig. 1 shows a few examples of the films deposited in our laboratory. All the films shown in the figure are specularly reflective. The bath compositions are stated in Section 2.1.

Fig. 2 illustrates the quality of the films: the transmittance, $T(\lambda) \%$, and the specular reflectance, $R(\lambda) \%$, add up to nearly 100 at wavelengths longer than the threshold for optical absorption across the band gap. Arrows in the figure indicate the values listed for the optical band gap $1.03 \mathrm{eV}(1204 \mathrm{~nm})$ and $1.88 \mathrm{eV}(659.5 \mathrm{~nm})$ for $\mathrm{Bi}_{2} \mathrm{Se}_{3}$ and $\mathrm{Sb}_{2} \mathrm{~S}_{3}$, respectively $[41,43]$.

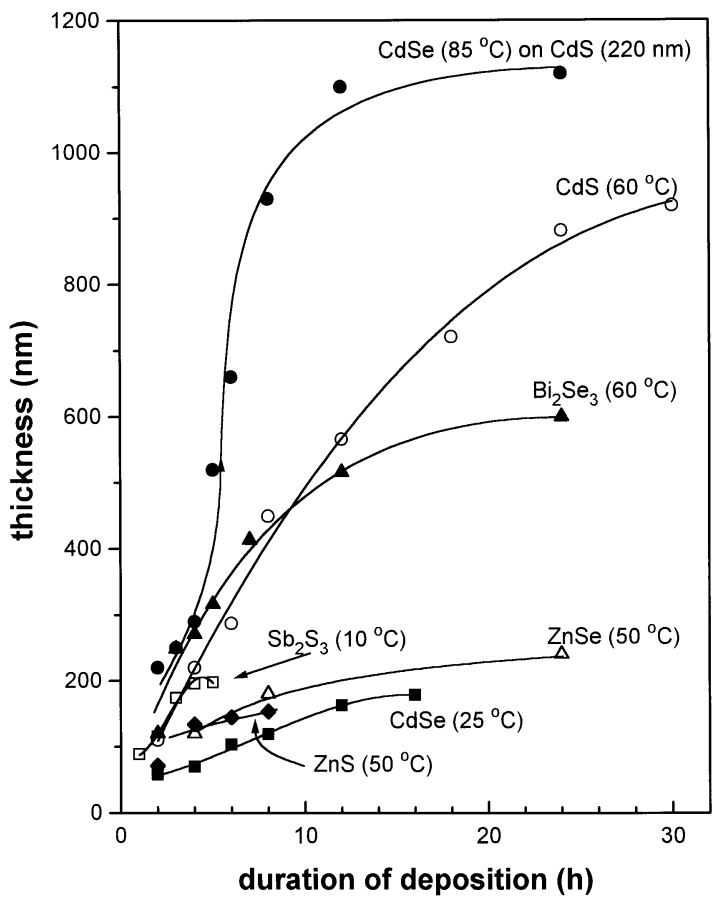

Fig. 1. Film thickness versus duration of deposition for different semiconductor thin films obtained by the chemical bath deposition technique. The bath temperature is indicated in parentheses; the bath composition is given in the text in Section 2.1. 


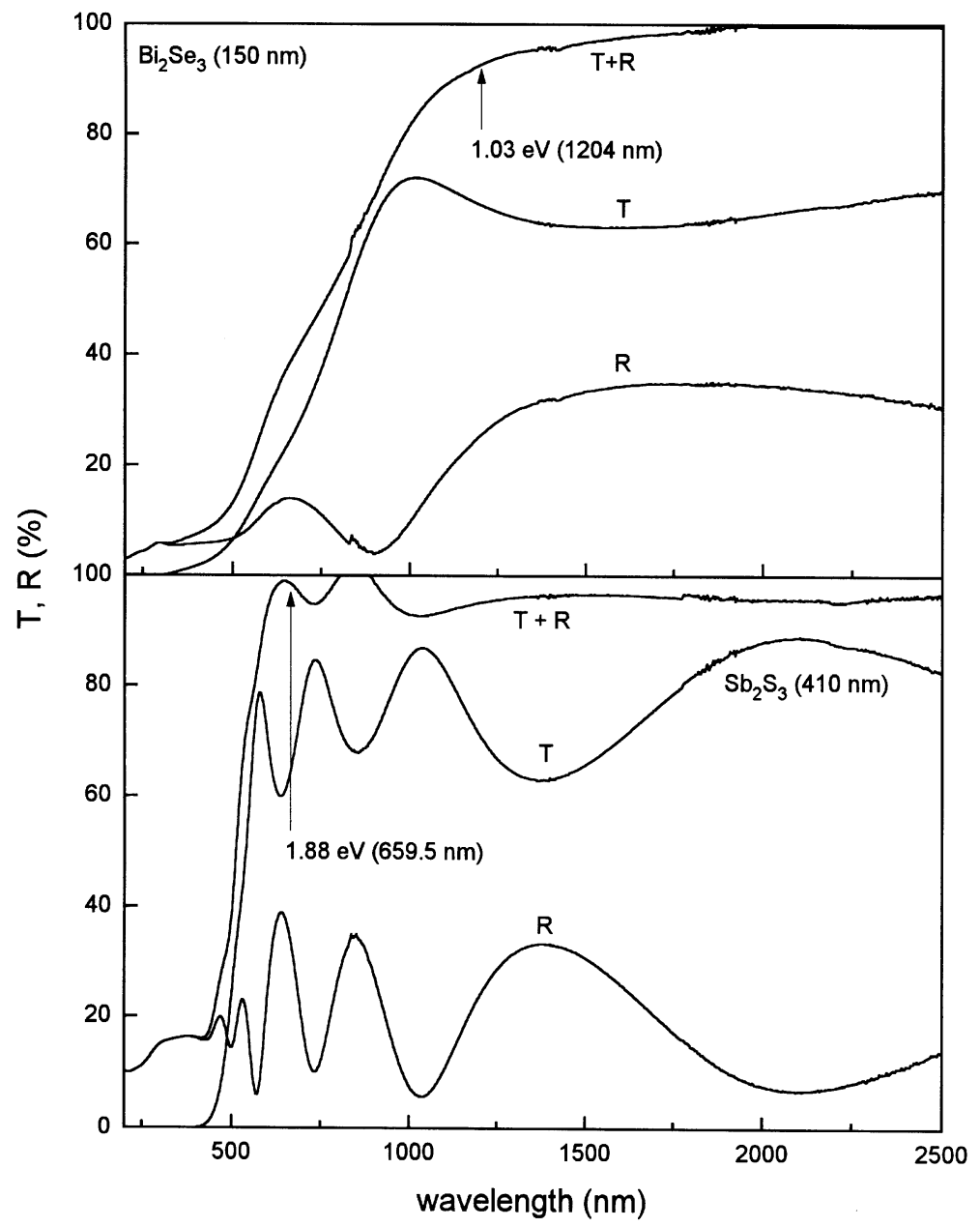

Fig. 2. The near-normal reflectance $(\mathrm{R} \%)$ and transmittance $(\mathrm{T} \%)$ curves of $\mathrm{Sb}_{2} \mathrm{~S}_{3}$ and $\mathrm{Bi}_{2} \mathrm{Se}_{3}$ thin films indicating the presence of interference peaks. The sum of $R(\%)+T(\%)$ is nearly $100 \%$ at long wavelengths, indicating that the films possess nearly smooth surfaces. Arrows indicate the positions of absorption edges reported in Refs. [41,43].

\subsection{Quantum confinement effect}

The effect of crystallite size on the optical band gap of semiconductor thin films has been discussed by many researchers [44]. It is known that for an electron in a quantum well of width $L$, the quantized energy levels $E_{n}$ are given by [45] $E_{n}=\frac{1}{2}(h / 2 \pi)^{2} \pi^{2} n^{2}\left(m_{\mathrm{e}}\right)^{-1} / L^{2}$. The ground-state energy is given by $E_{1}=\frac{1}{2}(h / 2 \pi)^{2}$ $\pi^{2}\left(m_{\mathrm{e}}\right)^{-1} / L^{2}$, where $h$ is the Planck's constant and $m_{\mathrm{e}}$ is the effective mass of electron. In the case of a polycrystalline semiconductor with crystalline grain width $L$, this leads to an enhancement of bandgap, $\left(E_{\mathrm{g}}\right)_{\mathrm{pc}}$ as compared to that of a bulk 
semiconductor crystal [46]:

$$
\left(E_{\mathrm{g}}\right)_{\mathrm{pc}}=\left(E_{\mathrm{g}}\right)_{\mathrm{bulk}}+\frac{1}{2}(h / 2 \pi)^{2} \pi^{2}\left(m_{\mathrm{e}}^{-1}+m_{\mathrm{h}}^{-1}\right) / L^{2}-(1.8 / \varepsilon L),
$$

where $m_{\mathrm{h}}$ is the effective mass for hole and the last term represents the screening term in a medium of permittivity $\varepsilon$. $\left(E_{\mathrm{g}}\right)_{\mathrm{pc}}$ approaches $\left(E_{\mathrm{g}}\right)_{\text {bulk }}$ for $L>50 \mathrm{~nm}$, but takes values considerably higher than the bulk value for $L<5 \mathrm{~nm}$. For example, in chemically deposited CdSe films with grain sizes $<5 \mathrm{~nm}$, optical band gap of up to $0.7 \mathrm{eV}$ higher than the bulk value (of $1.74 \mathrm{eV}$ ) has been reported [47].

Fig. 3 illustrates this effect in the case of $\mathrm{Sb}_{2} \mathrm{~S}_{3}$ thin films chemically deposited at $10^{\circ} \mathrm{C}$. The plots of square of the optical absorption coefficient $(\alpha)$ versus the photon energy $(h v)$ indicate direct band gaps for this film of about $0.7 \mathrm{eV}$ higher than the bulk value $(1.88 \mathrm{eV})$ for the band gap [43]. The grain size of these films are less than $5 \mathrm{~nm}$; the X-ray diffraction patterns did not indicate any diffraction peak. These results for $\mathrm{Sb}_{2} \mathrm{~S}_{3}$ films are in agreement with those reported by other workers [48].

\subsection{Preferential orientation of the films}

Preferential orientation of the crystallites perpendicular to the plane of the substrate is a common feature observed in the case of chemically deposited $\mathrm{CdS}$ and $\mathrm{CdSe}$

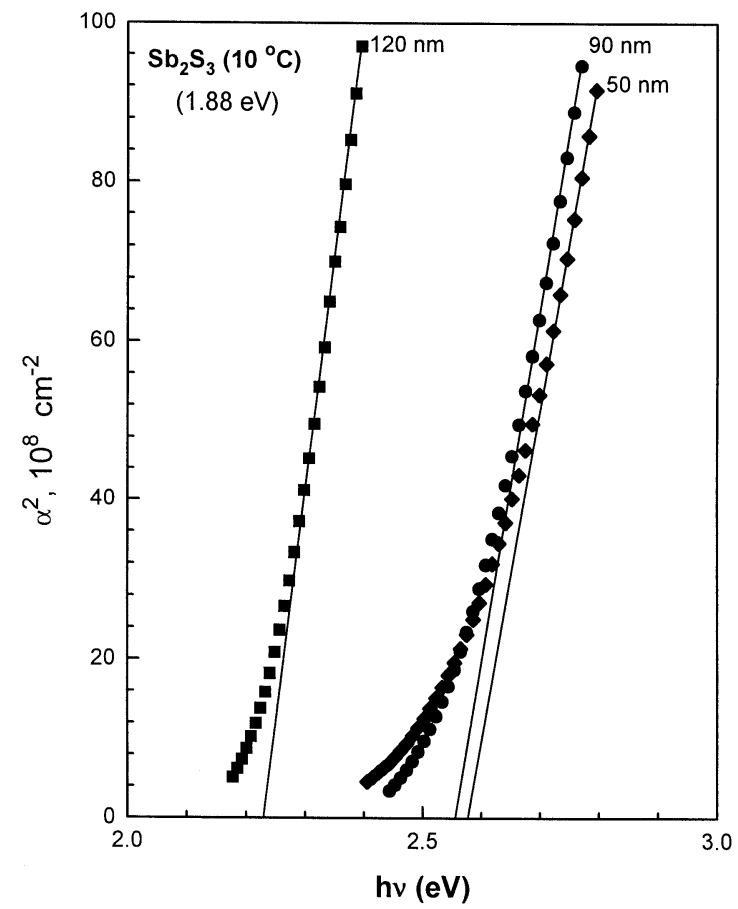

Fig. 3. The very small crystallites in chemically deposited thin films usually give rise to variation in band gaps due to quantum confinement effects; the case of $\mathrm{Sb}_{2} \mathrm{~S}_{3}$ films of 50,90 , and $120 \mathrm{~nm}$ thickness is illustrated. 


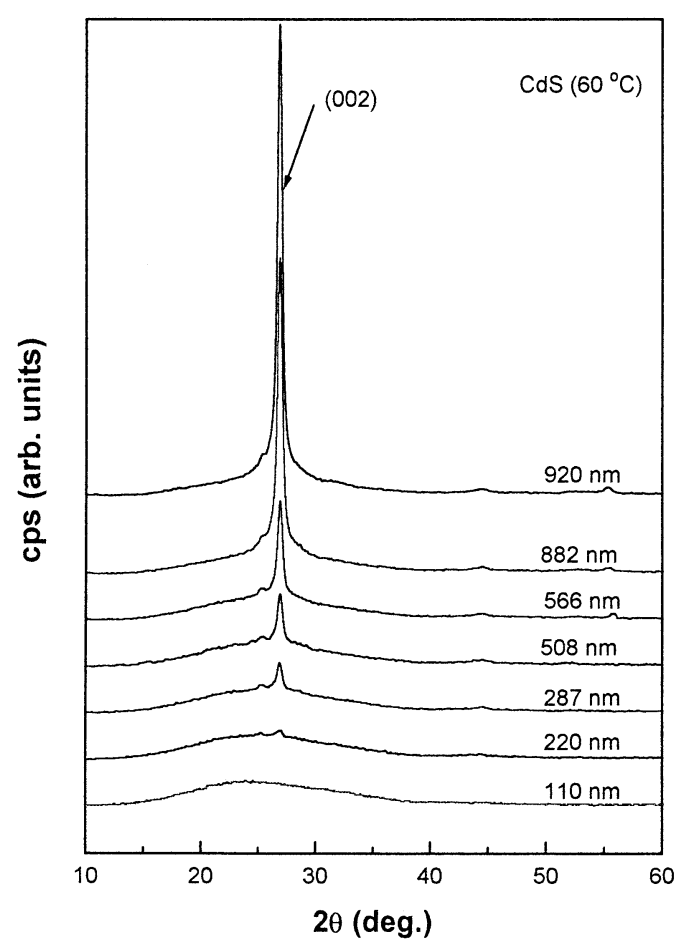

Fig. 4. Preferential orientation of the crystalline grain, with the $c$-axis perpendicular to the plane of the substrates is observed in the case of chemically deposited thin films in the thickness range $110-920 \mathrm{~nm}$.

thin films. Fig. 4 shows the typical case of CdS thin films deposited at $60^{\circ} \mathrm{C}$, using citrate as a complexing agent as described in Section 2.1. The orientation is so pronounced that only the diffraction peak corresponding to the $\left(\begin{array}{lll}0 & 0\end{array}\right)$ planes is noticeable. The figure also shows that at very small film thicknesses the films appear to be amorphous or possess very small crystallites.

\subsection{Photocurrent response}

Fig. 5 shows the photocurrent response of a number of chemically deposited thin films. Except for CdS, the films do not exhibit large changes in the current upon illumination. Most films are highly resistive in the dark; the electrical conductivities in the dark range from $10^{-8}$ to $10^{-6} \Omega^{-1} \mathrm{~cm}^{-1}$. Exceptions are $\mathrm{CuS}$ and $\mathrm{Cu}_{2-x} \mathrm{Se}$ thin films: the film conductivities are in the $10^{3}$ to $10^{4} \Omega^{-1} \mathrm{~cm}^{-1}$ range. Such high electrical conductivities produce free carrier absorption in the infrared region, very small optical transmittance and high reflectance in the infrared region. These features in the optical transmittance and reflectance spectra are shown in Fig. 6. The high electrical conductivity arises from copper deficiency in the films, which make them p-type [49]. This is a feature of copper chalcogenide films prepared by vacuum-based 


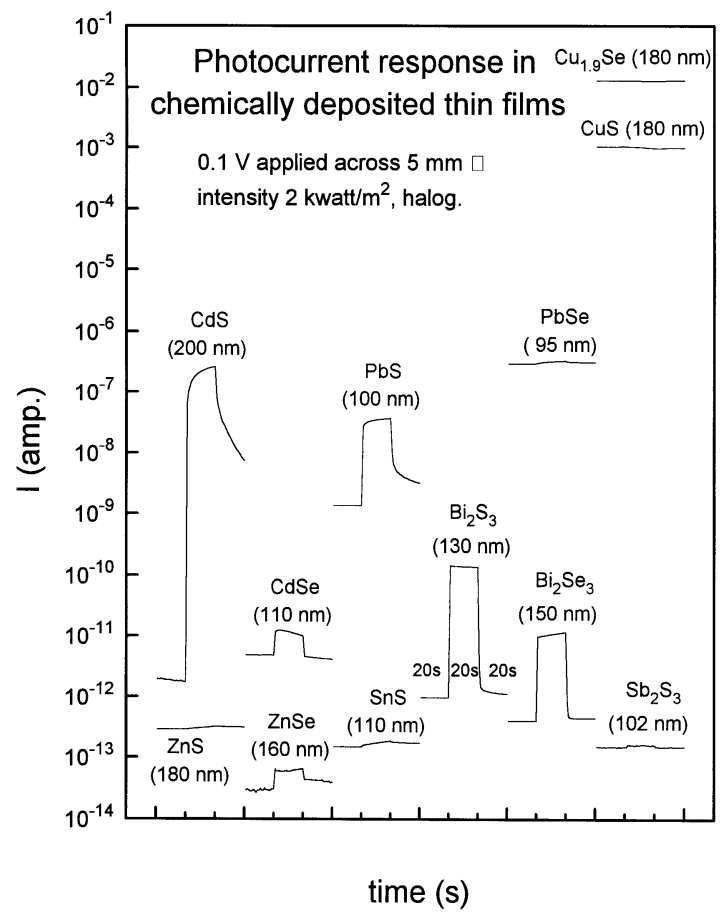

Fig. 5. Photocurrent response of various semiconductor thin films prepared in our laboratory by chemical bath deposition technique.

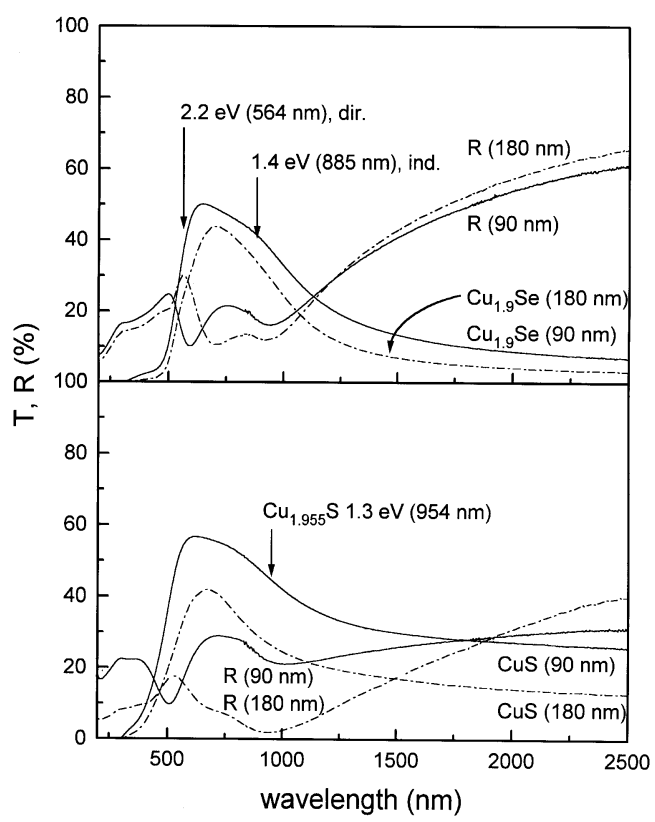




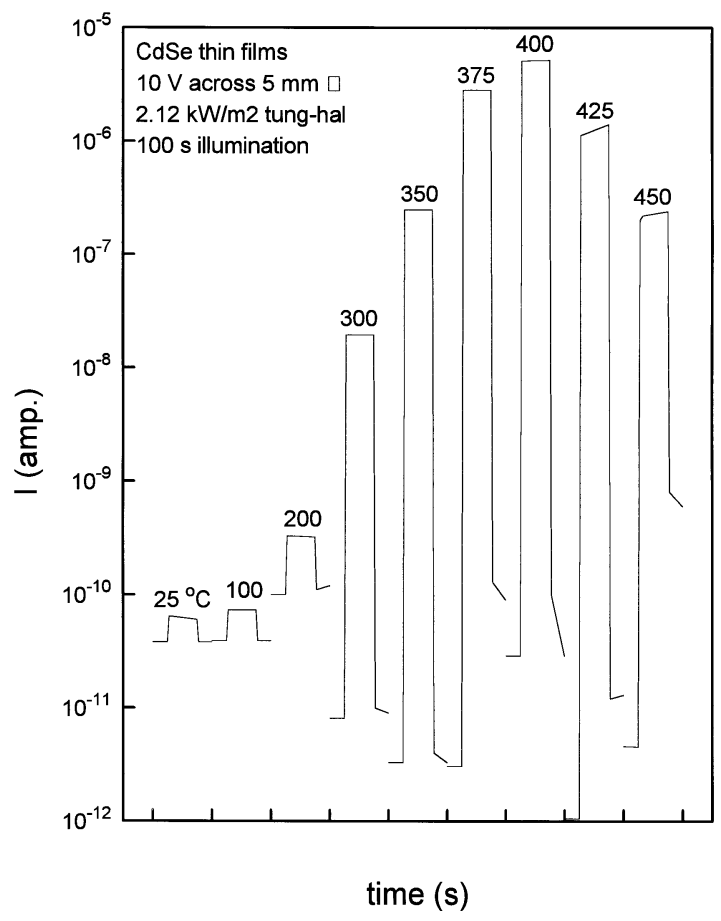

Fig. 7. Variation in the photosensitivity of the films produced by annealing of a CdSe film $(\sim 150 \mathrm{~nm})$ in air for $1 \mathrm{~h}$ each at different temperatures.

techniques as well [50]. The optical characteristics such as the one presented in Fig. 6 have been found to be ideal for application of these films in solar control glazing [51].

\subsection{Effect of air annealing on the photo response curves}

Air annealing leads to significant changes in the chemical, structural, electrical, and optical properties of chemically deposited semiconductor thin films. Notable examples are the following:

CdSe thin films: The as-prepared thin films possess very poor photosensitivity: $S=\left(I_{\mathrm{ph}}-I_{\mathrm{d}}\right) / I_{\mathrm{d}}$, where $I_{\mathrm{ph}}$ and $I_{\mathrm{d}}$ are the photocurrent and dark current, respectively. The CdSe thin films ( $\sim 0.18 \mu \mathrm{m}$ thickness $)$ in Fig. 7 were deposited at room temperature using $N-N$,dimethylselenourea as the source of selenide ions [33,34]. The photosensitivity increases from about 0.5 in as-deposited films to approximately $10^{6}$ after the film has been annealed in air at $375-425^{\circ} \mathrm{C}$ for $1 \mathrm{~h}$. This increase in

Fig. 6. Transmittance $(T \%)$ and near-normal reflectance $(R \%)$ curves of chemically deposited CuS thin films and $\mathrm{Cu}_{x} \mathrm{Se}$ thin films, indicating the high near-infrared reflectance and low infrared transmittance caused by the high electrical conductivities $\left(\sim 10^{3} \Omega^{-1} \mathrm{~cm}^{-1}\right)$ of the films shown in Fig. 5. Arrows indicate the positions of absorption edges reported in Ref. [43] for the materials of compositions shown. 
photosensitivity arises from the combined effect of grain size growth and chemisorption of oxygen in the intergrain region as discussed in earlier papers [33,34]. The mechanism of enhancement of charge carrier mobility in polycrystalline thin-film semiconductors as a function of grain size and illumination have been the subject of many earlier studies [52,53]. In short, the chemisorbed oxygen at the intergrain region builds up repulsive potential for the transport of electrons, leading to very low electron drift mobilities and hence produces only very small electric currents. Illumination produces electron-hole pairs, of which the holes neutralize the repulsive potential at the grain boundaries and leads to an exponential increase in the electron mobility. This results in a high photocurrent under illumination which combined with the very low current in dark produces a high photosensitivity in the films.

$C d S$ thin films: In sharp contrast with the effect of air annealing on the photosensitivity of CdSe thin films, the photosensitivity of the CdS thin films degrades under the same annealing process. Fig. 8 shows that the photosensitivity of asprepared films is nearly $10^{8}$, but annealing at temperatures $300-400^{\circ} \mathrm{C}$ lowers it to $10^{3}-10^{4}$. Annealing at higher temperatures improves the electrical conductivity drastically, as reported previously [31]. The increase in conductivity arises from the formation of a top layer of $\mathrm{CdO}$, which is highly n-type due to incomplete oxidation

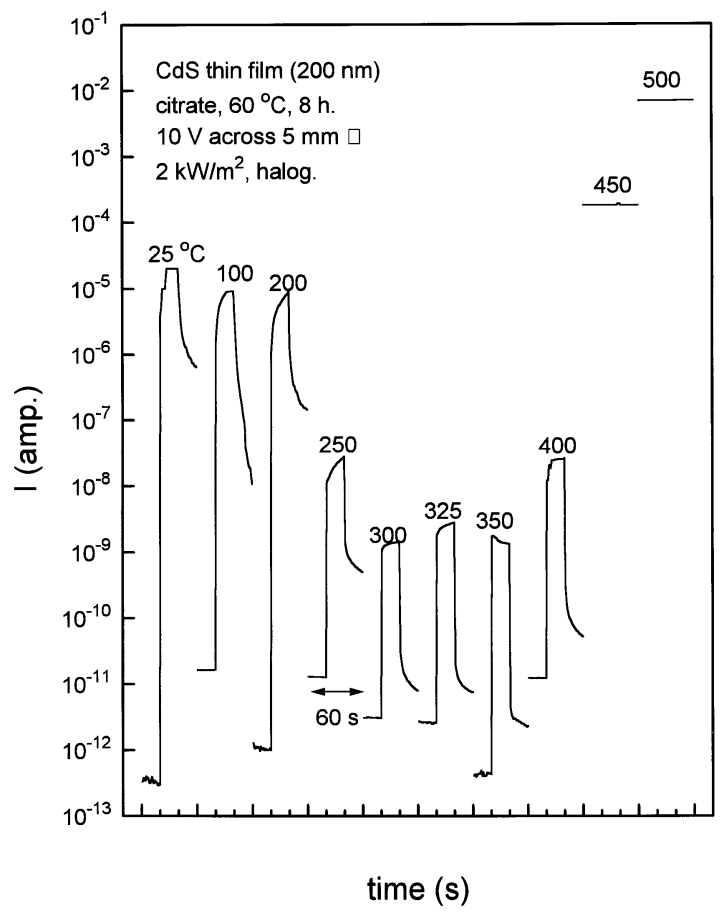

Fig. 8. Effect of annealing in air for $1 \mathrm{~h}$ each at different temperatures of a CdS thin film $(200 \mathrm{~nm})$ on the photocurrent response curves; the high electrical conductivities $\left(\sim 50 \Omega^{-1} \mathrm{~cm}^{-1}\right)$ of the film obtained after annealing at $500^{\circ} \mathrm{C}$ results from a partial conversion of the $\mathrm{CdS}$ films to a nonstoichiometric $\mathrm{CdO}_{1-x}$ film. 
which renders the $\mathrm{CdO}$ layer excess in $\mathrm{Cd}$. X-ray photoelectron spectroscopy studies indicated that the CdO surface layer resulted from the CdS film [31], and the X-ray diffraction studies showed that the conversion could not be completed during the air annealing process - the presence of the underlying CdS film could be detected along with the $\mathrm{CdO}$ component. Assuming that the $\mathrm{CdO}$ film thickness is of about $100 \mathrm{~nm}$ (over the CdS film) in the case of the film annealed at $500^{\circ} \mathrm{C}$ in Fig. 8, the electrical conductivity is seen to be approximately $100 \Omega^{-1} \mathrm{~cm}^{-1}$. Same range of conductivity is observed in $\mathrm{CdO}$ films produced by the oxidation of chemically deposited $\mathrm{Cd}(\mathrm{OH})_{2}$ films [54]. Annealing the CdS films, prepared by the citrate method, in an inert atmosphere is yet to be studied. It may be possible to identify the optimum annealing conditions which would result in improvement in the grain size and hence enhance the photoconductivity in these films without decomposition to oxide.

$\mathrm{ZnS}$ thin films: Fig. 9 shows that the $\mathrm{ZnS}$ thin films of about $200 \mathrm{~nm}$ deposited at $25^{\circ} \mathrm{C}$ are very resistive; sheet resistance is of nearly $10^{12} \Omega / \square$ and electrical conductivity (dark/photo) is nearly $10^{-8} \Omega^{-1} \mathrm{~cm}^{-1}$ Air annealing for $1 \mathrm{~h}$ at $388^{\circ} \mathrm{C}$ increases the photosensitivity to $\simeq 10^{4}$ and annealing at $450^{\circ} \mathrm{C}$ for $1 \mathrm{~h}$ increases the photoconductivity to $>0.05 \Omega^{-1} \mathrm{~cm}^{-1}$. The formation of a $\mathrm{ZnO}$ layer has been indicated by $\mathrm{X}$-ray diffraction studies. The formation, however, is not complete. XRF studies have shown

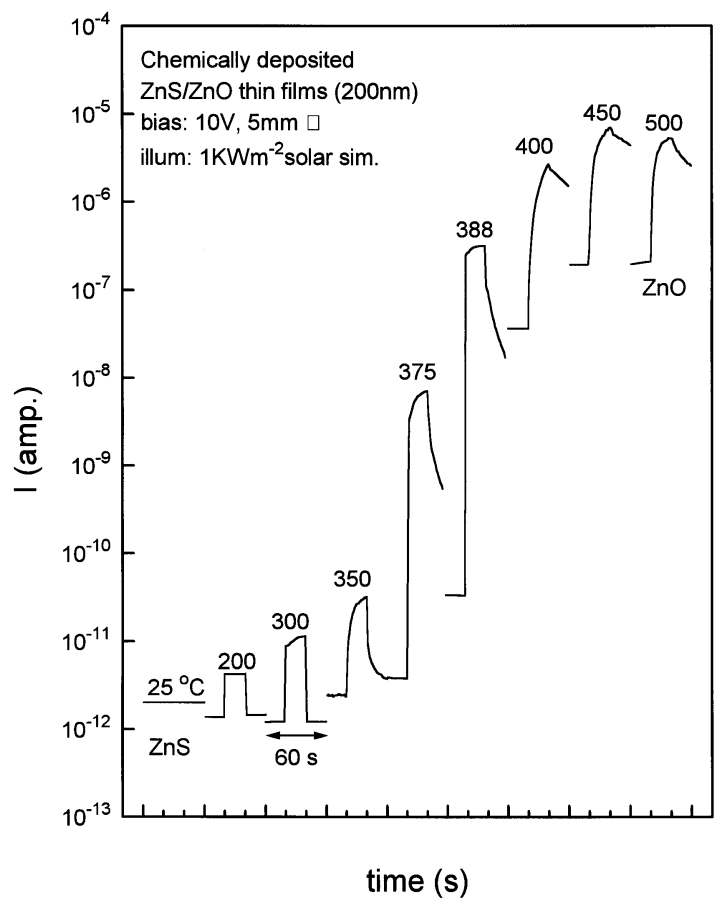

Fig. 9. The conversion of as-deposited, nonphotosensitive, $\mathrm{ZnS}$ thin film (200 $\mathrm{nm}$ thickness) to photosensitive thin film by air annealing at $375-388^{\circ} \mathrm{C}$, beyond which the films are partially converted to nonstoichiometric $\mathrm{ZnO}$ thin film, leading to electrical conductivities $>0.01 \Omega^{-1} \mathrm{~cm}^{-1}$. 
the presence of about $30 \%$ of the initial sulfur content in the films after they were annealed at $450^{\circ} \mathrm{C}-500^{\circ} \mathrm{C}$ for up to $2 \mathrm{~h}$. Thus, the $\mathrm{ZnO}$ is formed as a surface layer. The high conductivity arises from the incomplete oxidation, $\mathrm{ZnO}_{1-x}$, similar to the case of $\mathrm{CdO}$ films. Fig. 10 shows that the $\mathrm{ZnS}-\mathrm{ZnO}$ thin film maintains a high optical transmittance $\sim 80 \%$ in the near-infrared region and shows a shift in the optical band gap toward lower values. The $\alpha^{2}$ versus $h v$ plots for the film indicate band gap values of about $3.7 \mathrm{eV}$ for the as-prepared and $3.4 \mathrm{eV}$ for the $\mathrm{ZnS}-\mathrm{ZnO}$ film produced by air annealing at $500^{\circ} \mathrm{C}$ for $1 \mathrm{~h}$.

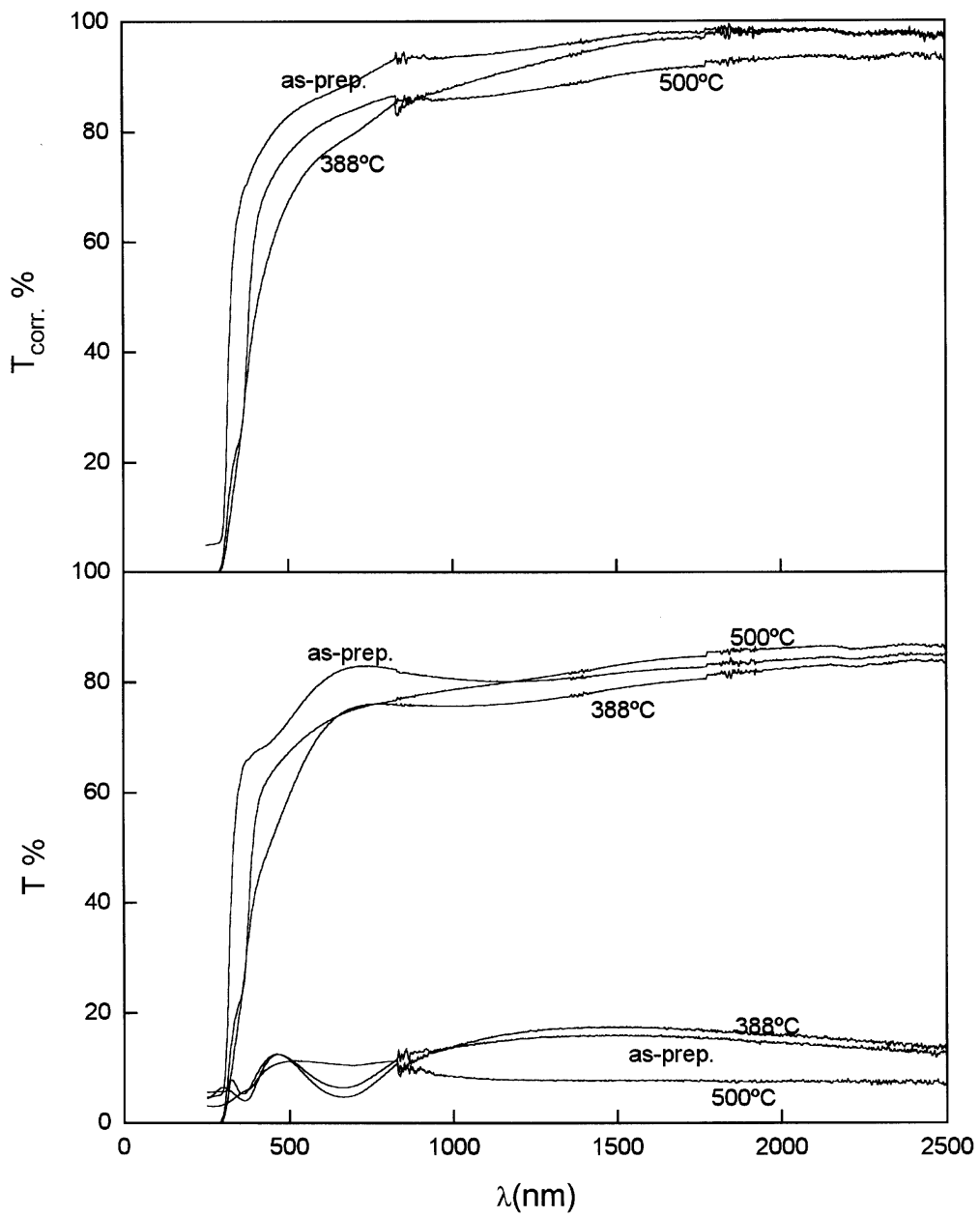

Fig. 10. The optical transmittance and reflectance spectra of a chemically deposited $\mathrm{ZnS}$ thin film, showing that the as-prepared and annealed $(\mathrm{ZnS} / \mathrm{ZnO})$ films possess high optical transmittance $\left(T_{\text {corr }} \%\right)$; $T_{\text {corr }}(\%)=100 \mathrm{~T} \% /(100 \mathrm{R} \%)$. 


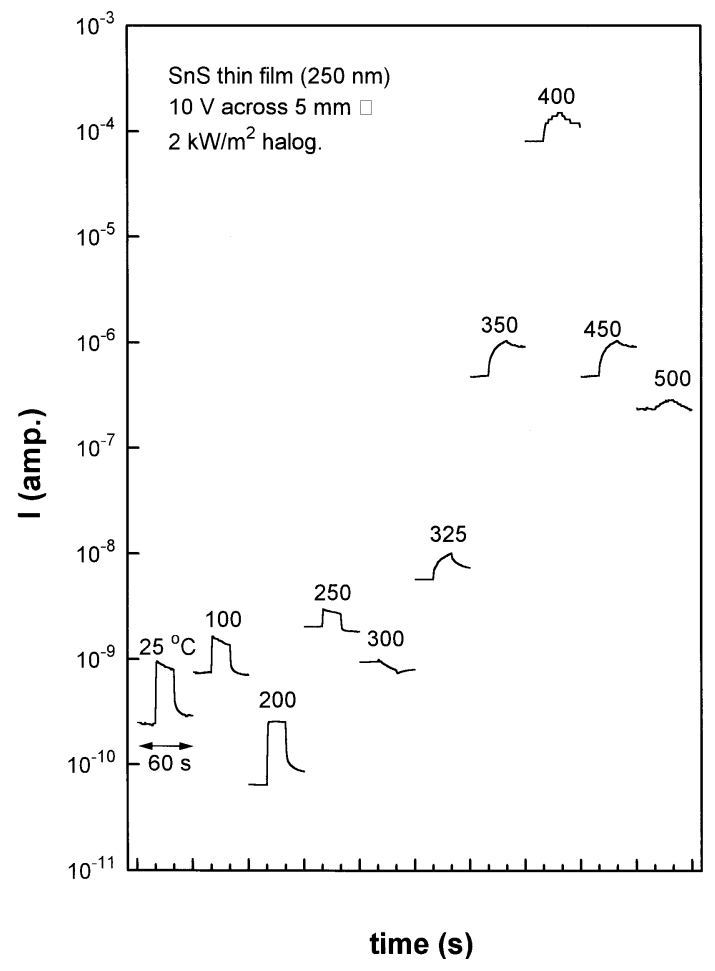

Fig. 11. Conversion of chemically deposited $\mathrm{SnS}$ thin films $(250 \mathrm{~nm})$ to $\mathrm{SnO}_{2}$ films $\left(400-500^{\circ} \mathrm{C}\right)$ by air annealing.

SnS thin films: The as-prepared films in this case are very resistive. Annealing at about $300^{\circ} \mathrm{C}$ leads to the partial conversion of $\mathrm{SnS}$ to $\mathrm{SnO}_{2-x}$; the nonstoichiometry leads to high electrical conductivities. The proportion of $\mathrm{SnO}_{2-x}$ in the film increases with temperature. Fig. 11 shows that at $400^{\circ} \mathrm{C}$ the conductivity of the film is the highest, about $0.5 \Omega^{-1} \mathrm{~cm}^{-1}$. At this annealing temperature the $\mathrm{SnS}$ thin film, which originally appears orange-red in transmitted daylight becomes nearly transparent [55]. Annealing at temperatures above $400^{\circ} \mathrm{C}$ retains the film transparent, but leads to a better stoichiometry, $\mathrm{SnO}_{2}$, which increases the resistance of the films.

3.6. Conversion of chemically deposited films to n-type by ion exchange reactions and diffusion of indium

In earlier papers we have discussed that immersion of $\mathrm{CdS}$ thin films in a dilute solution $(0.05 \mathrm{M})$ of $\mathrm{HgCl}_{2}$ for a few minutes and annealing in air at $200^{\circ} \mathrm{C}$ for a few minutes produces n-type conductivity of $\sim 1 \Omega^{-1} \mathrm{~cm}^{-1}$ in the films [31]. This conductivity is stable during storage in desiccator over a period of several months. Similar improvements in electrical conductivity are observed in CdSe thin films as 


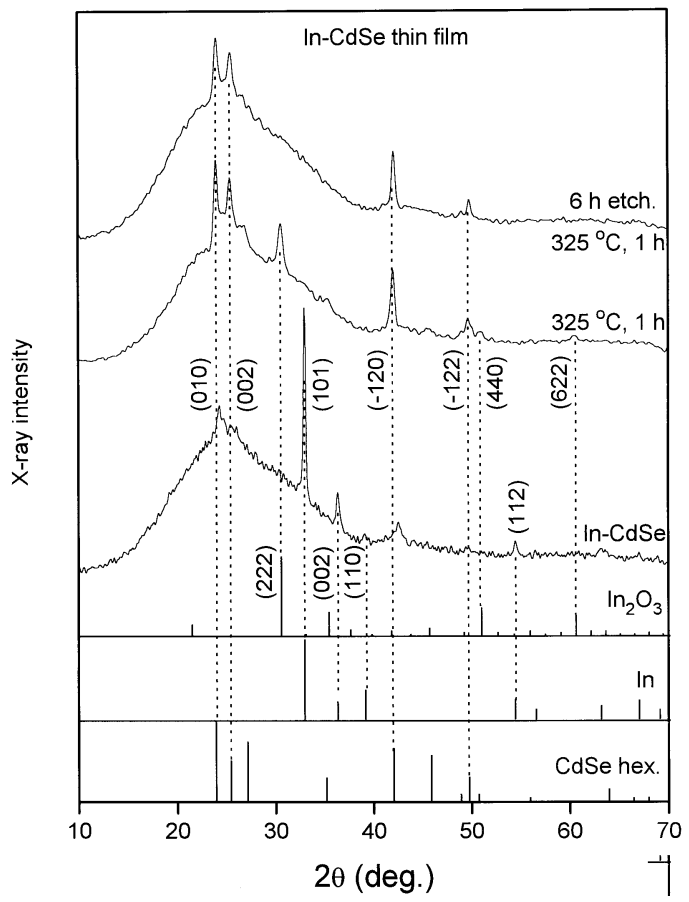

Fig. 12. Conversion of chemically deposited CdSe thin films to n-type through deposition of a $20 \mathrm{~nm}$ indium film on the CdSe film $(150 \mathrm{~nm})$ and subjecting it to air annealing at $325^{\circ} \mathrm{C}$ for $1 \mathrm{~h}$. A chemical etch for $6 \mathrm{~h}$ in a $1 \mathrm{M} \mathrm{HCl}$ solution removes the top $\mathrm{In}_{2} \mathrm{O}_{3}$ layer, which exposes the underlying CdS : In layer.

well [56]. The increase in conductivity has been attributed to the incorporation of chlorine in the film. The drawback of this type of conversion to n-type is loss of the conductivity at higher annealing temperatures $\left(300^{\circ} \mathrm{C}\right.$ or above).

Recently, we reported another technique to convert the chemically deposited CdS [57,58] and CdSe thin films to n-type [59]. Fig. 12 illustrates the basic mechanism involved. A $20 \mathrm{~nm}$ thick indium film is evaporated over a chemically deposited CdSe thin film of about $150 \mathrm{~nm}$ thickness [59]. The quantity of indium required for this is about $15 \mathrm{mg}$ to cover an area of $150 \mathrm{~cm}^{2}$ of the film surface. Annealing at $300-350^{\circ} \mathrm{C}$ produces an $\mathrm{In}_{2} \mathrm{O}_{3}$ surface layer, which may be removed by etching in $1 \mathrm{M} \mathrm{HCl}$ solution. The underlying film is indiumdoped CdSe, i., CdSe : In. Fig. 13 shows that the conductivity of such a film is high: nearly $1 \Omega^{-1} \mathrm{~cm}^{-1}$ as compared to that of the CdSe film $\left(10^{-7} \Omega^{-1} \mathrm{~cm}^{-1}\right)$ annealed in air under the same conditions. The conductivity was found to be stable during desiccated storage.

Fig. 14 shows that thermal diffusion of indium does not inevitably produce n-type conductivity by substitution of a divalent metal in chemically deposited thin films. In the case of a $20 \mathrm{~nm}$ indium film deposited over a $\mathrm{PbS}$ thin film, metallic lead is 


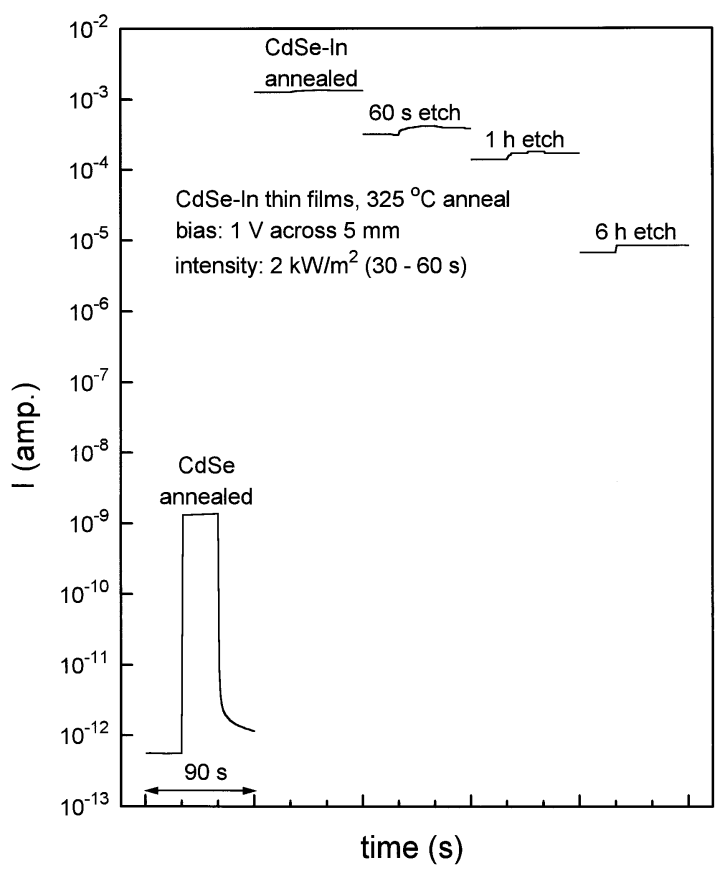

Fig. 13. Photocurrent response of annealed CdSe-In films, showing that a conductive $\operatorname{In}_{2} \mathrm{O}_{3}$ layer is formed on the film, which can be etched away in $1 \mathrm{M} \mathrm{HCl}$ solution. The underlying film after a $6 \mathrm{~h}$ etch is devoid of the $\mathrm{In}_{2} \mathrm{O}_{3}$ film (Fig. 12), but possesses a dark conductivity of $3 \Omega^{-1} \mathrm{~cm}^{-1}$, nearly seven orders of magnitude higher than that of a CdSe film annealed under the same conditions.

precipitated in the medium, resulting from a reaction of the type

$$
y \mathrm{PbS} \text { (crystalline) }+x \operatorname{In} \rightarrow \operatorname{In}_{x} \mathrm{~S}_{y} \text { (amorphous) }+y \mathrm{~Pb} \text { (crystalline). }
$$

This reaction takes place when the films are annealed at $300^{\circ} \mathrm{C}$, and produces a composite material. The conductivity of this film is high: $500 \Omega^{-1} \mathrm{~cm}^{-1}$ and sheet resistance is about $100 \Omega^{-2}$.

\subsection{Conversion of chemically deposited thin films to p-type by ion exchange reactions} and interfacial diffusion

The conversion of chemically deposited CdS thin films to p-type by topotaxial reaction in a $\mathrm{CuCl}$ solution of $\mathrm{pH} 3.7$ at $90^{\circ} \mathrm{C}$ for about $10 \mathrm{~s}$ has been developed as a method to produce $\mathrm{CdS}-\mathrm{Cu}_{2} \mathrm{~S}$ solar cells in the 1980s [60]. The incorporation of copper ions in chemically deposited CdSe thin films by immersion in a dilute solution of $\mathrm{CuCl}_{2}(0.005 \mathrm{M})$ has been reported before [56] from our group. The presence of $\mathrm{Cd}_{x} \mathrm{Cu}_{y} \mathrm{Se}_{z}$ composition in the surface layer, as evidenced in the XPS studies, gives rise to very low sheet resistance (and of p-type conductivity) of $10^{5} \Omega / \square$ as compared to $10^{12} \Omega / \square$ of the CdSe films. The same is the case with $\mathrm{ZnSe}$ thin films as well: 


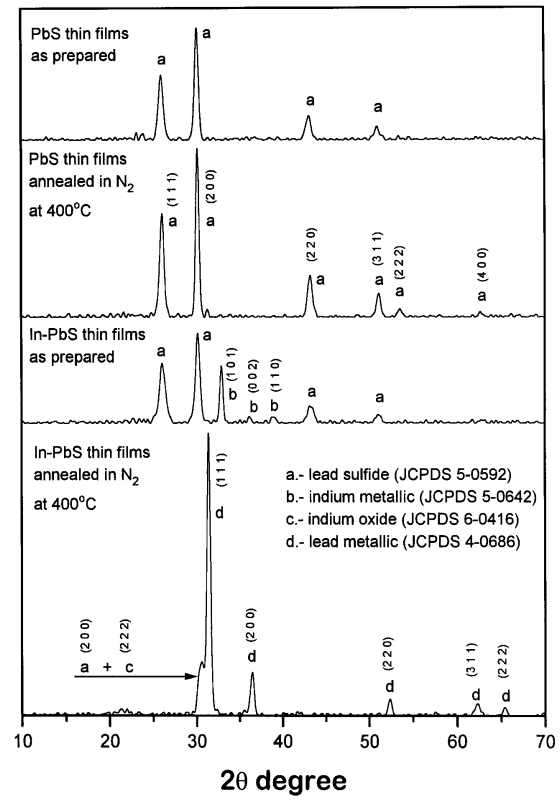

Fig. 14. XRD patterns illustrating that annealing in nitrogen of a $\mathrm{PbS}(200 \mathrm{~nm})-\operatorname{In}(20 \mathrm{~nm})$ film results in the formation of metallic lead crystallites and the dispersion of indium in the matrix; the presence of which is detected in the X-ray flourescence spectra.

immersion for about $1 \mathrm{~min}$ of a $\mathrm{ZnSe}$ thin film in a $0.025 \mathrm{M} \mathrm{CuCl}_{2}$ solution reduces the sheet resistance from about $10^{12} \Omega / \square$ to $10^{3} \Omega / \square$ through the formation of a $\mathrm{Zn}_{x} \mathrm{Cu}_{y} \mathrm{Se}_{z}$ composition on the surface layer [61].

Production of thermally stable thin films of p-type conductivity of about $300 \Omega^{-1} \mathrm{~cm}^{-1}$ (sheet resistance of about $100 \Omega / \square$ ) is possible through interfacial diffusion of metal atoms in $\mathrm{ZnS}-\mathrm{CuS}$ or $\mathrm{PbS}-\mathrm{CuS}$ multilayers [5]. The films are stable in the temperature range $150-350^{\circ} \mathrm{C}$ under air annealing. More interesting results were obtained when $\mathrm{Bi}_{2} \mathrm{~S}_{3}-\mathrm{CuS}$ films were annealed. The formation of a new compound $\mathrm{Cu}_{3} \mathrm{BiS}_{3}$ (wittichenite) was suggested in a previous paper [62] and detailed results are presented in a recent paper [6]. Fig. 15 illustrates the mechanism of formation of the new film. Annealing the $\mathrm{Bi}_{2} \mathrm{~S}_{3}-\mathrm{CuS}$ films at temperatures of $200-300^{\circ} \mathrm{C}$ results in the interfacial diffusion of metal ions and formation of the new compound through the reaction

$$
\mathrm{Bi}_{2} \mathrm{~S}_{3}+6 \mathrm{CuS} \rightarrow 2 \mathrm{Cu}_{3} \mathrm{BiS}_{3}+3 \mathrm{~S} .
$$

The excess sulfur may be removed by immersion in a suitable solvent. The conductivity of the resulting film is $>100 \Omega^{-1} \mathrm{~cm}^{-1}$. This indicates that many chemically deposited thin films involving $\mathrm{Cu}_{2-x} \mathrm{Se}, \mathrm{CuSe}, \mathrm{CuS}$ and $\mathrm{Cu}_{x} \mathrm{~S}$ may be subjected to suitable annealing process to produce multinary compounds. 


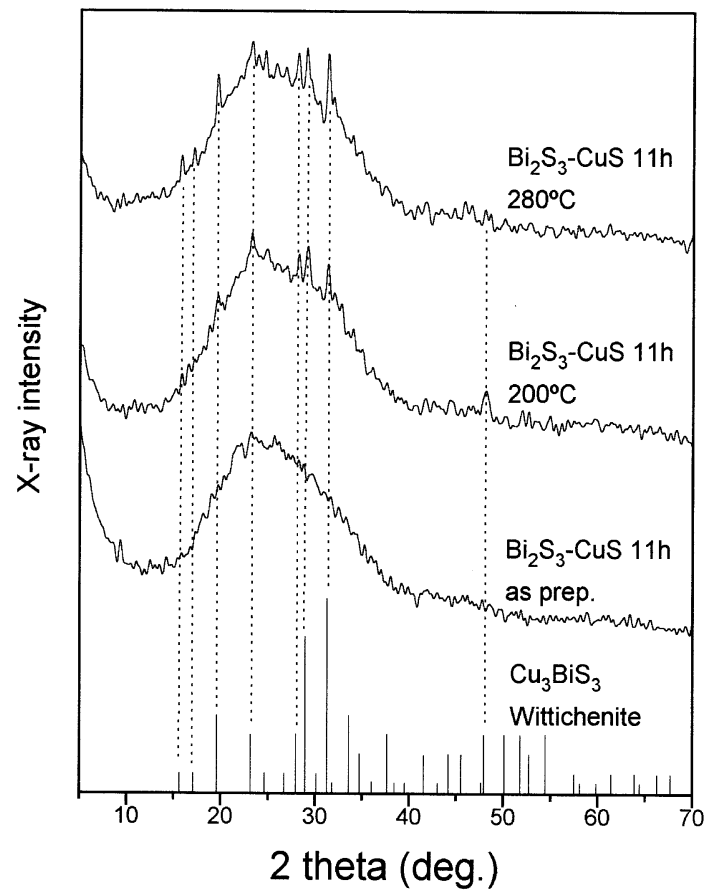

Fig. 15. The formation of a new material, $\mathrm{Cu}_{3} \mathrm{BiS}_{3}$ (mineral sample; wittichenite) during annealing at $200-280^{\circ} \mathrm{C}$ of a chemically deposited $\mathrm{Bi}_{2} \mathrm{~S}_{3}-\mathrm{CuS}$ thin film (X-ray source, $\mathrm{Cu} \mathrm{K}$ ).

\subsection{Use of the precipitate as a precursor for other coating techniques}

The real challenge in the optimization of a chemical bath deposition technique is to reduce the particulate precipitate in the bath obtain in high thin-film yield. Nevertheless, even in the best optimized bath, precipitate presents itself as a major product of the condensation process. The precipitate may be filtered and reacted with acids to produce the starting materials for deposition. But, in many cases the precipitate may be rinsed well, dried and stored to serve as precursor for other deposition techniques. Following are the three specific examples:

(i) Screen printing technique: The basic principles involved in screen printing process for producing semiconductor coatings have been discussed in Ref. [63]. This technique has been successfully used in the production of CdS-CdTe solar cells [64]. The screen printing process involves the preparation of a paste containing the semiconductor pigment, a flux material which will fuse at a temperature much below the melting point of the pigment, and a binder usually ethylene glycol or propylene glycol. The paste is printed on suitable substrates using a silk screen or polyester screen, dried for a few hours at $50-80^{\circ} \mathrm{C}$, and then sintered at a temperature higher than the melting point of the flux. Fig. 16 illustrates the physicochemical changes that occur during the sintering process [65]. Here, CdSe precipitate recovered from a chemical deposition bath [33,34] was mixed with $30 \%$ by weight of $\mathrm{ZnCl}_{2}$ 


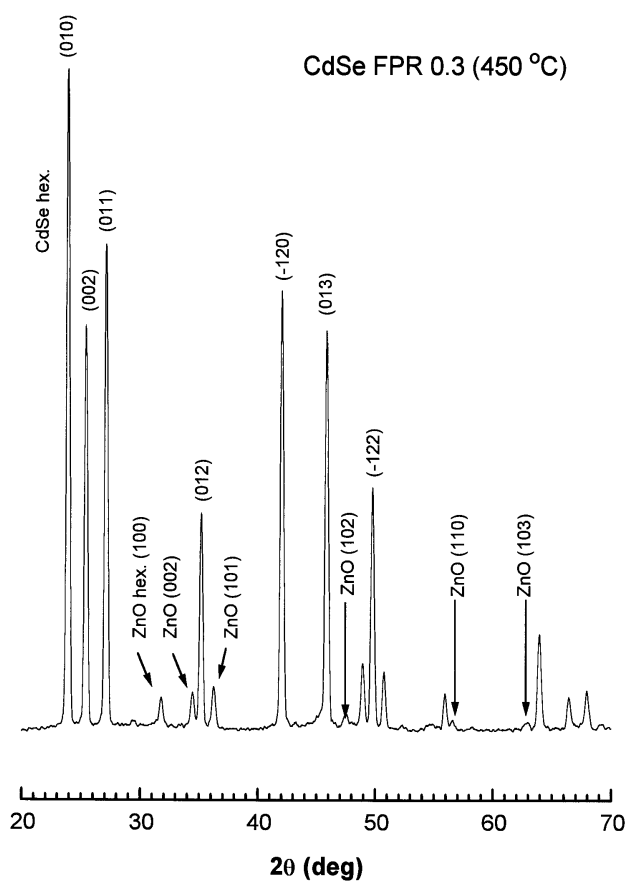

Fig. 16. X-ray $\left(\mathrm{Cu} \mathrm{K}_{\alpha}\right)$ diffraction pattern of a screen-printed and sintered $\left(450^{\circ} \mathrm{C}\right) \mathrm{CdSe} / \mathrm{ZnO}$ layer prepared using CdSe precipitate and $30 \%$ by weight of $\mathrm{ZnCl}_{2}$ as flux (flux-to-pigment ratio, $\mathrm{FPR}=0.3$ ) dispersed in propylene glycol.

(anhydrous) and sufficient quantity of propylene glycol to produce a screen printing paste. The paste was screen printed on to glass substrates using a $120 \mathrm{~T}$ polyester screen (approx. mesh: sieve opening $44 \mu \mathrm{m}$ and filament diameter $30 \mu \mathrm{m}$ ). The coating was dried in an air oven at $110^{\circ} \mathrm{C}$ for $1 \mathrm{~h}$ and sintered at $350-450^{\circ} \mathrm{C}$ in air for $1 \mathrm{~h}$ each. The XRD pattern in Fig. 16 for the coating sintered at $450^{\circ} \mathrm{C}$ shows well-defined peaks of $\mathrm{CdSe}$ and $\mathrm{ZnO}$. A possible mechanism is that at temperatures above the melting point of $\mathrm{ZnCl}_{2}$, it melted and covered the CdSe pigment. At the sintering temperature $\mathrm{ZnCl}_{2}$ combined with atmospheric oxygen forming $\mathrm{ZnO}$. XRF studies have indicated that the chlorine content of the film has been significantly reduced in the sintered film - up to $10 \%$ of its original value in the dried screen printed coating.

Fig. 17 illustrates the high photosensitivity achieved in the screen printed film prepared as above. The best photosensitivity, $\sim 10^{8}$, is obtained for a sintering temperature of $450^{\circ} \mathrm{C}$. Photosensitivity of even higher than this (for example, $10^{9}$ under air mass one solar radiation) has been obtained in chemically deposited CdS thin films $[66,67]$. However, the fast decay of photocurrent of the screen printed $\mathrm{CdSe} / \mathrm{ZnO}$ coatings is not matched by them.

(ii) Use in the production of composite coatings: Fig. 18 shows the sheet resistance of composite coatings made of $\mathrm{CuS}$ pigments precipitated from a chemical bath used for thin-film deposition [42] dispersed in poly(acrylic acid) (molecular weight assay 


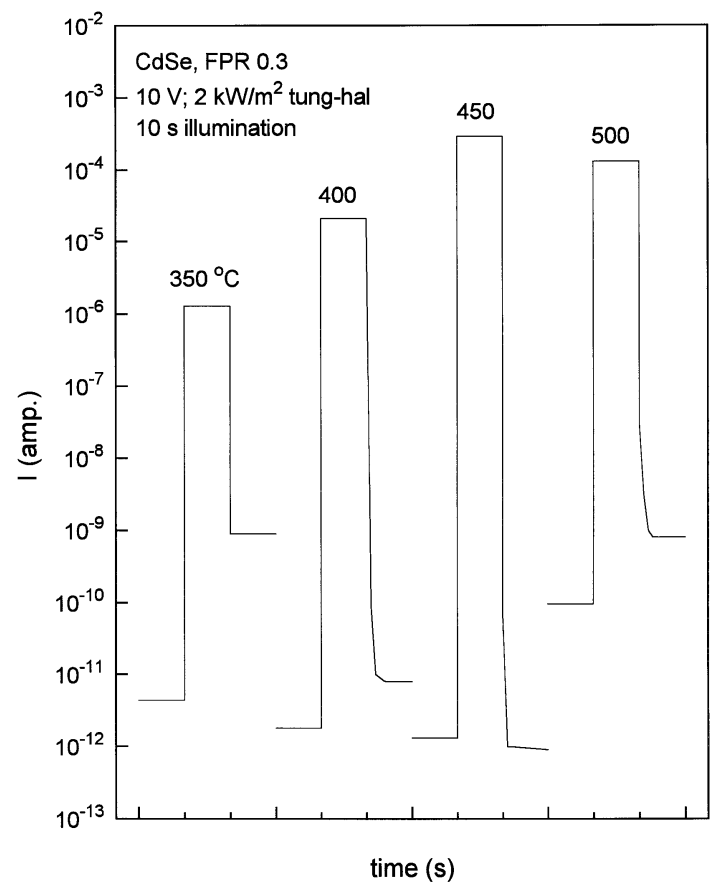

Fig. 17. Photocurrent response ( $10 \mathrm{~s}$ dark, $10 \mathrm{~s}$ illumination, and $10 \mathrm{~s}$ dark) of the screen-printed $\mathrm{CdSe} / \mathrm{ZnO}$ coating as a function of sintering temperature.

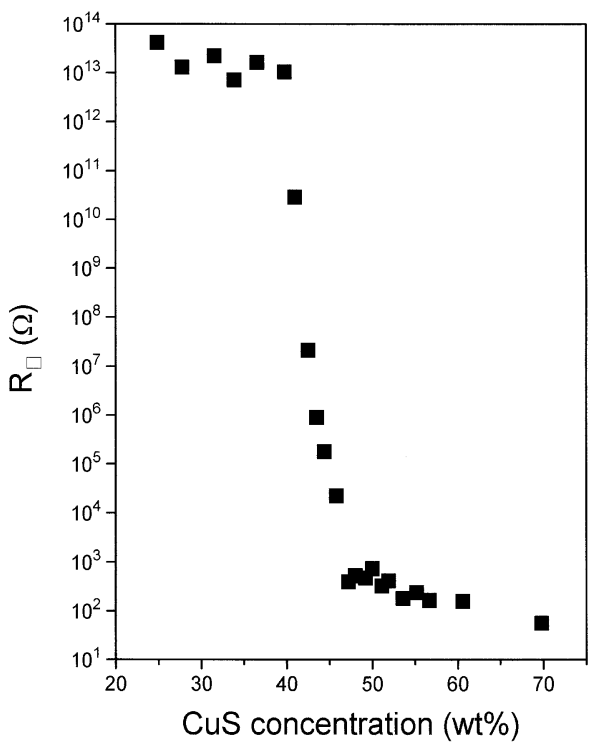

Fig. 18. Sheet resistance of CuS-polyacrylic acid composite coatings, where the CuS precipitate was obtained from a chemical deposition bath. The $\mathrm{CuS}$ weight percentage indicates the percentage weight of $\mathrm{CuS}$ component in the total weight of the composite, poly (acrylic acid) plus the precipitate. 


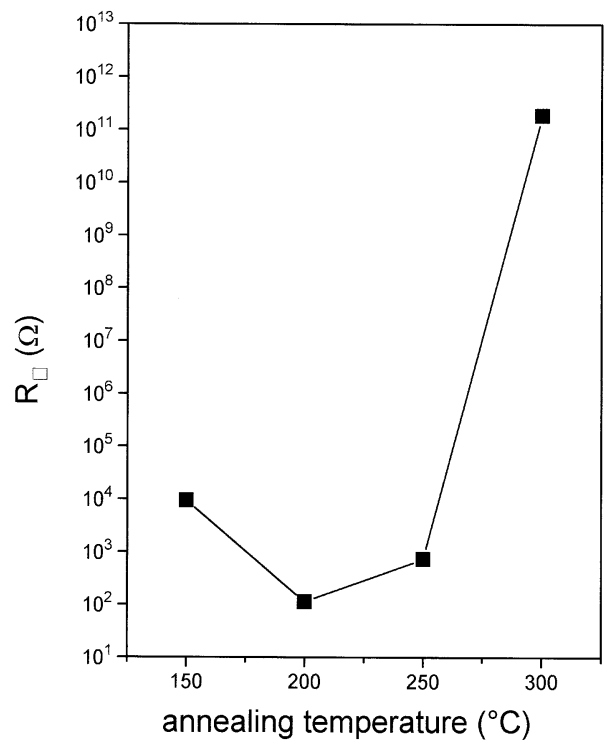

Fig. 19. Variation of sheet resistance in CuS-poly acrylic acid composite coatings with temperature of annealing.

90000 ), with propylene glycol used as a solvent. The conductivity percolation is seen at $40 \% \mathrm{w} / \mathrm{w}$ of $\mathrm{CuS}$ powder in the total weight of the composite. Sheet resistance of nearly $100 \Omega / \square$ is obtained at a wt\% of about $55 \% \mathrm{CuS}$. Higher $\mathrm{wt} \%$ of the precipitate makes the surface of the coating rough. The results shown are for coatings annealed at $200^{\circ} \mathrm{C}$. Fig. 19 shows that the conductivity does not degrade considerably when annealed at a temperature up to $250^{\circ} \mathrm{C}$. Above this, there is chemical conversion of the $\mathrm{CuS}$ component to digenite, $\mathrm{Cu}_{9} \mathrm{~S}_{5}$, (JCPDS 26-0476) as illustrated in Fig. 20 and a transition of the coating to an insulator. The conversion may take place through the release of sulfur into the polymer matrix, for example, $15 \mathrm{CuS} \rightarrow 6 \mathrm{CuS}+\mathrm{Cu}_{9} \mathrm{~S}_{5}+4 \mathrm{~S}$. The resulting changes in chemical bonding have been studied by FTIR and discussed in Ref. [68].

(iii) Use of the precipitate as the source for vapor phase deposition: The semiconductor precipitate produced in the chemical deposition bath is, in general, stoichiometric. The purity of the precipitate is superior to that of the starting chemicals in the bath because the impurities whose concentrations are below those required for precipitation into solid phase (i., ionic product $<$ solubility product) are left behind in the solution. Thus, the precipitate can serve as a relatively pure source of semiconductor material for vapor phase deposition. In a recent study we used the bismuth sulfide precipitate recovered from a bath [39] normally used for depositing thin films. The dried powder was placed in the center zone of a tubular vacuum furnace (10 mTorr) and heated to $500^{\circ} \mathrm{C}$. Glass substrates were placed along the axis of the tubular furnace from the center of the furnace downstream toward the pumping outlet, with 


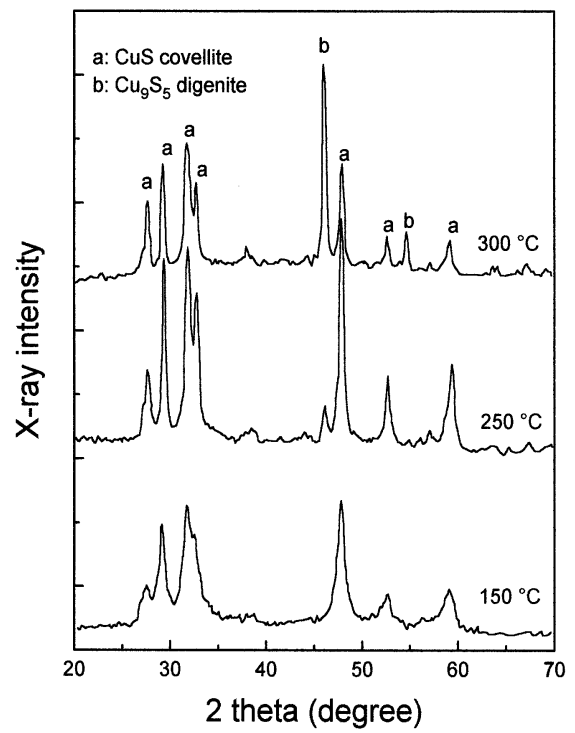

Fig. 20. Partial conversion of the $\mathrm{CuS}$ (covellite) precipitate in the composite coatings to $\mathrm{Cu}_{9} \mathrm{~S}_{5}$ (digenite) when the coatings are annealed at $300^{\circ} \mathrm{C}$.

the temperature dropping to nearly $150^{\circ} \mathrm{C}$ at the far end. The geometry of the vapor phase deposition set up is discussed in Ref. [69].

Fig. 21 shows that the film deposited at a substrate temperature of $345^{\circ} \mathrm{C}$ during $5 \mathrm{~h}$ from the bismuth sulfide precipitate maintained at $500^{\circ} \mathrm{C}$ presents well-defined peaks. Even though there is a general agreement of the peak positions with that of standard $\mathrm{Bi}_{2} \mathrm{~S}_{3}$ (bismuthinite, JCPDS 17320), the intensity ratios observed in the film vary from that of the powder sample. This indicates preferential orientation of the crystallites. Fig. 22 shows the plot of the square of the product of the optical density $(\mathrm{o} . \mathrm{d})=(\alpha \mathrm{d}) / 2.303$ (where $\alpha$ is the absorption coefficient and $d$ the thickness of the film) and the photon energy $E=h c / \lambda$ (where $h$ is the Planck's constant; $c$ the velocity of light; and $\lambda$ the wavelength of radiation). The thin films possess a wide range of direct optical band gaps from 1.0 to $2.0 \mathrm{eV}$, depending on the temperature of the substrate. The range of photosensitivity, $S=\left(I_{\mathrm{ph}}-I_{\mathrm{d}}\right) / I_{\mathrm{d}}=\left(\sigma_{\mathrm{ph}}-\sigma_{\mathrm{d}}\right) / \sigma_{\mathrm{d}}$ (where $I_{\mathrm{ph}}$ and $\sigma_{\mathrm{ph}}$ are the photocurrent and photoconductivity, respectively, and $I_{\mathrm{d}}$ and $\sigma_{\mathrm{d}}$ are the dark current and dark conductivity, respectively) varies widely as shown in Fig. 23. High electrical conductivity is typical of films deposited at higher substrate temperatures. Thus, the optical and electrical properties of the films may be varied depending on the chosen substrate temperature to suit specific applications of the films.

\subsection{Chemically deposited semiconductor thin films for solar energy related applications}

Major advantages of the chemical bath deposition for solar energy applications: Two major characteristics of solar energy are well recognized: (i) It is abundant in most part 


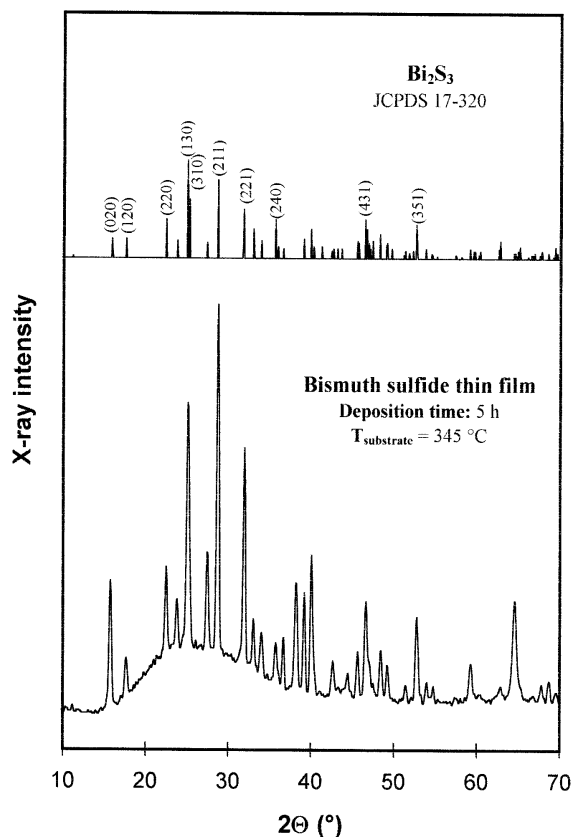

Fig. 21. XRD patterns of bismuth sulfide thin films deposited with substrate temperature of $345^{\circ} \mathrm{C}$ using bismuth sulfide precipitate as source, source temperature, $500^{\circ} \mathrm{C}$ at $4000 \mathrm{~Pa}$. Standard patterns for $\mathrm{Bi}_{2} \mathrm{~S}_{3}$ (bismuthinite) is given for the sake of comparison.

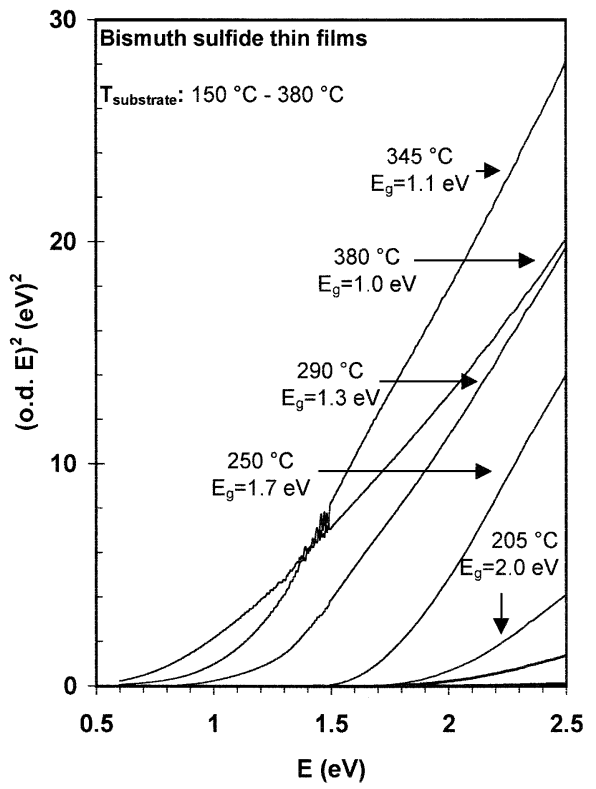




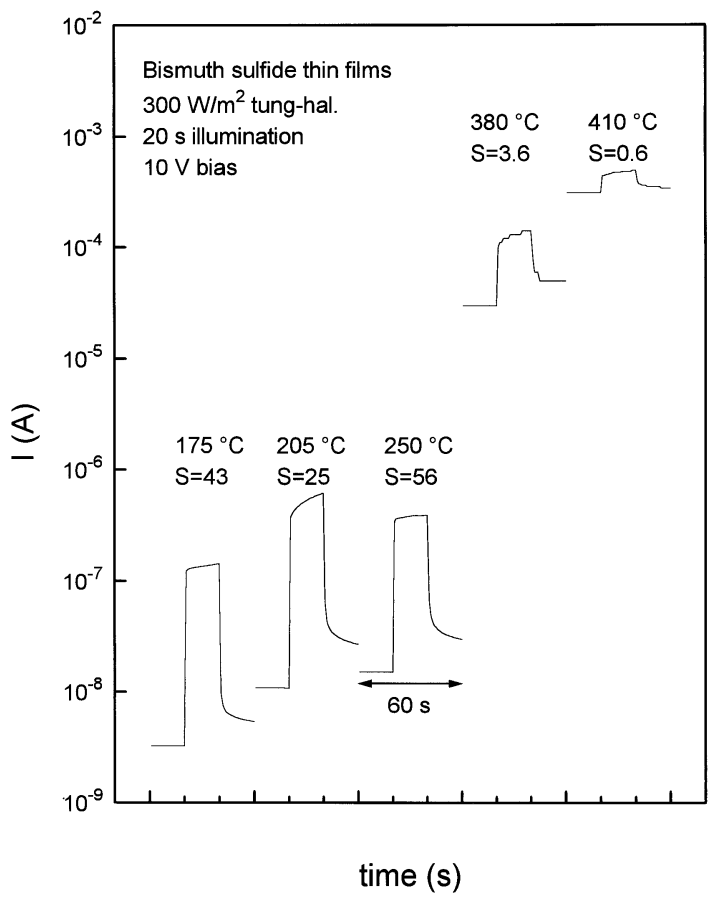

Fig. 23. Photocurrent response of bismuth sulfide thin films deposited from vapor phase at different substrate temperatures using bismuth sulfide precipitate as the source. The values of photosensitivity $S$ are given.

of the world; and (ii) it is available in a relatively dilute form, typically $20 \mathrm{MJm}^{-2} /$ day, as compared with nearly $30 \mathrm{MJ} / \mathrm{kg}$ obtainable from coal or petroleum. Collection of solar energy over a large area is inevitable. Chemical bath deposition is considered to be excellent in producing semiconductor thin films over large areas for such applications.

(i) Application in solar control coatings: In previous papers we have described the application of various chemically deposited semiconductor thin films for this purpose $[12,13]$. The basic purpose of this application is to reduce space cooling expenses in buildings and in automobiles by selectively controlling the amount of visible and infrared radiation entering through glazings. Chemically deposited $\mathrm{CuS}$ thin films have been found to possess near-ideal solar control characteristics: transmittance in the visible region of $20-50 \%$, low transmittance, $10-20 \%$, in the infrared region, low reflectance, $<10 \%$, in the visible region so as to avoid glare, and relatively higher reflectance, $>15 \%$, in the near-infrared region [70]. The coatings can be made on

Fig. 22. Variation in the optical band gap of bismuth sulfide thin films deposited at different substrate temperatures $\left(205-380^{\circ} \mathrm{C}\right)$ from vapor phase using bismuth sulfide precipitate as the source (source temperature, $500^{\circ} \mathrm{C}$; pressure: $4000 \mathrm{~Pa}$ ). 
sheet glass, acrylic, or polyester sheet and foils with equal ease [71]. To impart versatility and improvement of adhesion of the film to glass substrate, substrate films of chemically deposited $\mathrm{PbS}$ [72], $\mathrm{SnS}$ [73], $\mathrm{ZnS}$ [35], $\mathrm{Bi}_{2} \mathrm{~S}_{3}$ [74], and $\mathrm{ZnS}-\mathrm{NiS}$ [75] have been proposed. A major problem in the application of these films was the need for a protective coating. The use of an aromatic polyurethene-based commercial transparent varnish was tried with limited success [76].

We have recently concluded that the best way to use chemically deposited solar control coatings is in the form of a laminated glazing. In this configuration, coatings were made on $3 \mathrm{~mm}$ thick commercial sheet glass and then laminated using a commercially available laminating polymer sheet of $0.4 \mathrm{~mm}$ thickness. This is a proprietary copolymer [77] of polyvinyl butyryl-acetate - alcohol with other ingredients added in order to prevent degradation of the polymer by the ultraviolet component of solar radiation. The lamination, of glass + coatingpolymer-clear sheet glass, was done in an autoclave at $140^{\circ} \mathrm{C}$ under $2 \mathrm{~kg} \mathrm{~cm}^{-2}$ pressure for about $3 \mathrm{~h}$.

Fig. 24 illustrates the transmittance and reflectance spectra of two different coatings $\mathrm{CuS}$ and $\mathrm{PbS}-\mathrm{CuS}$, where the individual coating thicknesses are of the order of $0.1 \mu \mathrm{m}$. The spectra were recorded for incidence from the side of the coated glass - the recommended mode of incidence to minimize entry of the ultraviolet component of solar radiation into the polymer. The calculation of integrated reflectance $(R)$ and transmittance $(T)$ in the visible (vis) and infrared (ir) were calculated for air mass two solar spectrum as described in Ref. [12]. The implication of these values in the solar control parameters of the glazing is discussed in Ref. [13]. The visible transmittance, $T_{\text {vis }}$, of $51 \%$ and visible reflectance, $R_{\text {vis }}$, of $12 \%$ of the laminated CuS coatings are suitable for use in automobile glazing and combination of $T_{\text {vis }}=21 \%, R_{\mathrm{vis}}=18 \%$, and $R_{\mathrm{ir}}=28 \%$ of the laminated $\mathrm{PbS}-\mathrm{CuS}$ coating are suitable for architectural glazing applications.

(ii) Application as solar absorber coatings: Chemically deposited $\mathrm{SnS}-\mathrm{CuS}$ [78], $\mathrm{PbS}-\mathrm{CuS}$ and $\mathrm{Bi}_{2} \mathrm{~S}_{3}-\mathrm{CuS}$ [79] coatings have been investigated by us for application as absorber coating in all-glass tubular solar collectors. The efficiency of such coatings has been analyzed in a theoretical model [11]. It was apparent that the absorber coating must be located on the outside of the inner glass tube. The stability of the coating in the vacuum zone at operating temperature of $300^{\circ} \mathrm{C}$ is therefore the major issue to be addressed. In the case of $\mathrm{PbS}-\mathrm{CuS}$ and $\mathrm{ZnS}-\mathrm{CuS}$ thin films, thermal stability at temperatures of up to $350^{\circ} \mathrm{C}$ has been observed to be satisfactory during air annealing [5]. The solar absorptance of a $\mathrm{PbS}-\mathrm{CuS}$ film is about 0.87 and thermal emittance is less than 0.46 (corresponding to sheet resistance of the annealed film of about $32 \Omega \square$ [79]. As per theoretical prediction [11], such a coating can offer conversion efficiency of about $50 \%$ at an $f$-value of $0.1^{\circ} \mathrm{C} \mathrm{m}^{2} \mathrm{~W}^{-1}$. This value is not very attractive compared to what may be offered by coatings produced by vacuum techniques [80]. However, the advantage of chemical bath deposition in producing uniform coatings on glass tubes is substantial over vacuum techniques. Further work on the thermal stability of chemically deposited multilayer films in vacuum at $300-400^{\circ} \mathrm{C}$ is worth considering to develop this application. 


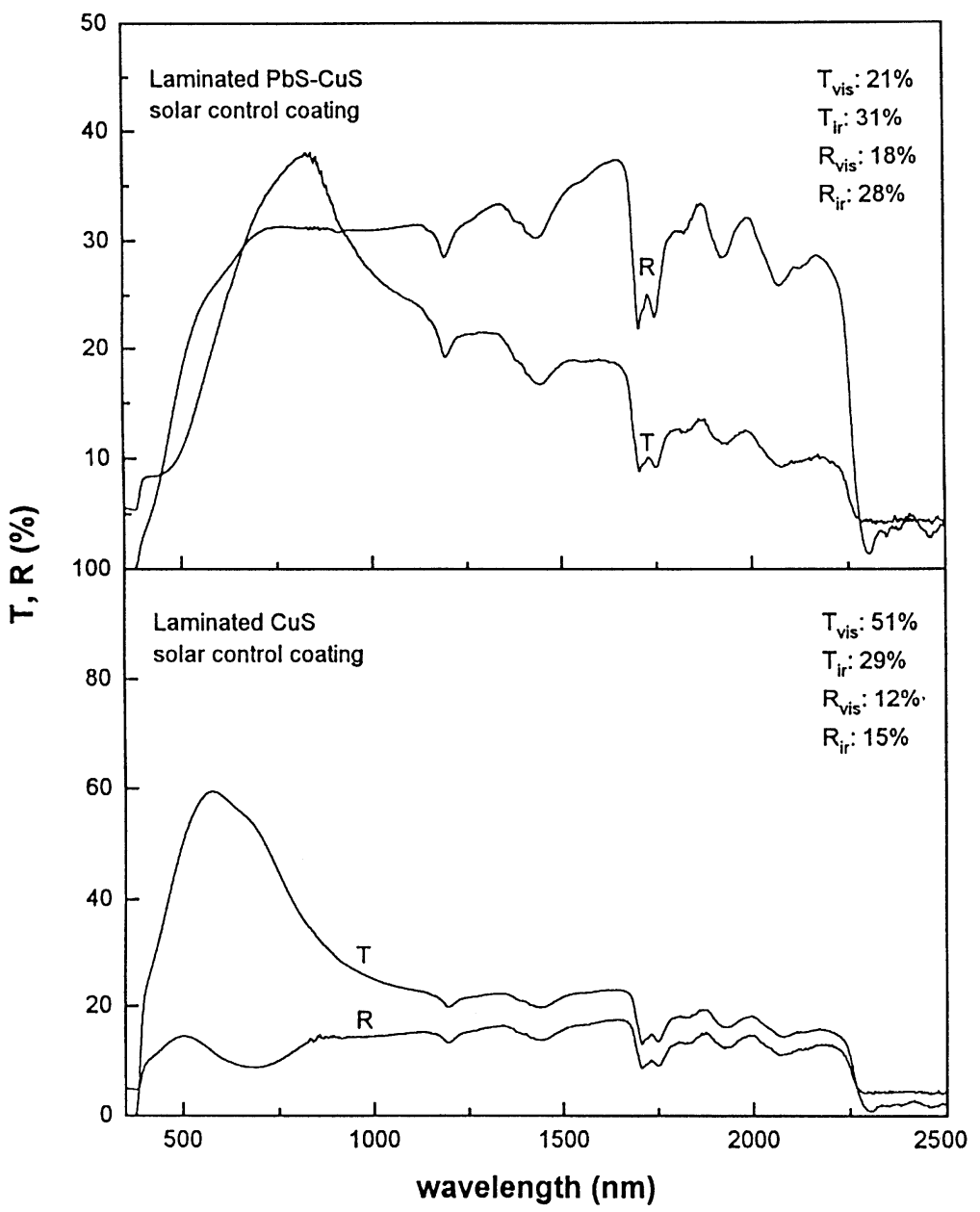

Fig. 24. Optical transmittance and reflectance of $\mathrm{CuS}$ and $\mathrm{PbS}-\mathrm{CuS}$ coatings deposited on $3 \mathrm{~nm}$ thick commercial window glass and laminated with a clear window glass $(3 \mathrm{~mm})$ using commercial-grade laminating polymer [77]. Laminating process: $140^{\circ} \mathrm{C}$ under $2 \mathrm{~kg} / \mathrm{cm}^{2}$ pressure for $2 \mathrm{~h}$.

(iii) Photodetector and photovoltaic applications: Fig. 25 shows the dependence of the photoresponse curve of chemically deposited CdSe thin films as a function of the intensity of illumination. The dependence of the photocurrent on the intensity is nearly linear. The photo generation of such magnitude in the depletion layer of a Schottky barrier or $\mathrm{p}-\mathrm{n}, \mathrm{p}-\mathrm{i}-\mathrm{n}$ junction leads to the build up of photo voltage. We consider that the possibility of creating new materials through interfacial diffusion of atoms in chemically deposited multilayer stacks as demonstrated in $\mathrm{PbS}-\mathrm{CuS}$, $\mathrm{ZnS}-\mathrm{CuS}$ and $\mathrm{Bi}_{2} \mathrm{~S}_{3}-\mathrm{CuS}$ films $[5,6]$ is very high. Table 1 suggests a list of possible absorber materials for photovoltaic application chosen from the data given in 


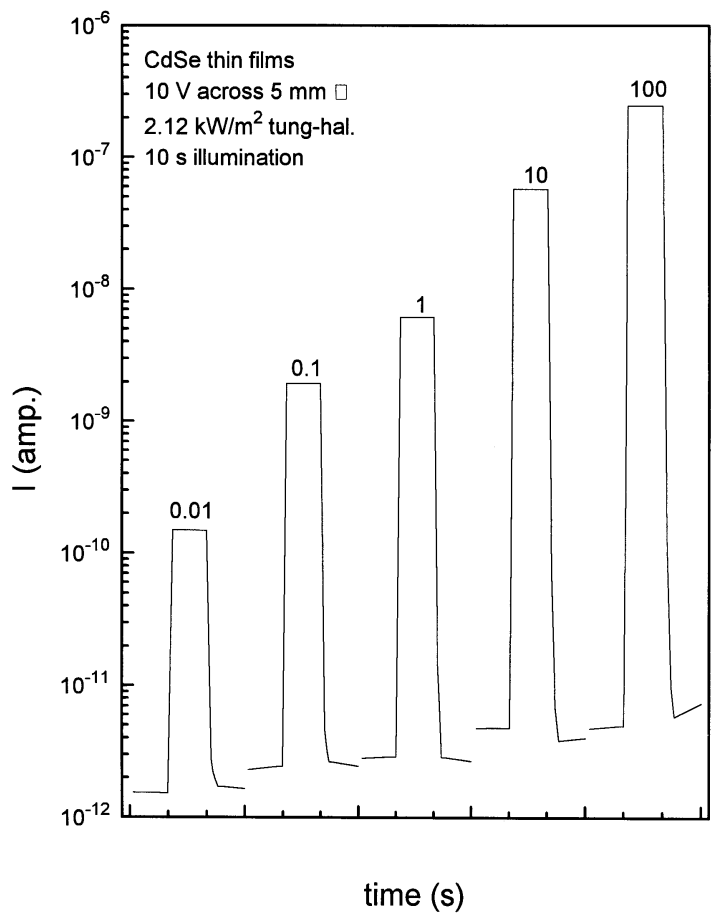

Fig. 25. Photoresponse curves of a CdSe thin film annealed in air at $450^{\circ} \mathrm{C}$ at different illumination levels $(0.01 \%), 0.2 \mathrm{~W} \mathrm{~m}^{-2}$ and to $100 \%, 2.12 \mathrm{~kW} \mathrm{~m}^{-2}$ illustrating near-linear dependence of photocarrier generation on the intensity of illumination - a basic feature on which photovoltaic effect depends.

Table 1

Suggestions for the development of new solar cell/solar energy materials which may be prepared through the interfacial diffusion of ions in multilayer chemically deposited thin films during annealing. The data have been extracted from Ref. [43]

\begin{tabular}{lllc}
\hline Material & Structure & Band gap (eV) & $\begin{array}{c}\text { Hole mobility } \\
\left(\mathrm{cm}^{2} / \mathrm{Vs}\right)\end{array}$ \\
\hline $\mathrm{CuSbSe}_{2}$ & Orthorhombic & 0.83 & 5 \\
$\mathrm{AgSbS}_{2}$ & Monocl. & 1.73 & 1500 \\
$\mathrm{AgSbSe}_{2}$ & Rock salt & 0.58 & \\
$\mathrm{AgBiS}_{2}$ & Rock salt & 0.9 & \\
$\mathrm{Cu}_{3} \mathrm{SbS}_{4}$ & Zincblende & 0.46 & 50 \\
$\mathrm{Cu}_{3} \mathrm{SbSe}_{4}$ & Zincblende & 0.31 & 910 \\
$\mathrm{Ag}_{2} \mathrm{SnSe}_{3}$ & & 0.81 & 870 \\
$\mathrm{Cu}_{2} \mathrm{SnSe}_{3}$ & & 0.96 & 605 \\
$\mathrm{Cu}_{2} \mathrm{SnS}_{3}$ & 0.91 & \\
$\mathrm{PbSnS}_{3}$ & & 1.05 & \\
\hline
\end{tabular}


Ref. [43], which may be produced by solid-state reaction of the type

$$
\begin{aligned}
& 2 \mathrm{CuS}+\mathrm{SnS} \rightarrow \mathrm{Cu}_{2} \mathrm{SnS}_{3}\left(E_{\mathrm{g}}=0.91 \mathrm{eV}\right), \\
& \mathrm{PbS}+\mathrm{SnS}_{2} \rightarrow \mathrm{PbSnS}_{3}\left(E_{\mathrm{g}}=1.05 \mathrm{eV}\right), \\
& \mathrm{Bi}_{2} \mathrm{~S}_{3}+\mathrm{Ag}_{2} \mathrm{~S} \rightarrow 2 \mathrm{AgBiS}_{2}\left(E_{\mathrm{g}}=0.9 \mathrm{eV}\right), \\
& \mathrm{Sb}_{2} \mathrm{~S}_{3}+\mathrm{Ag}_{2} \mathrm{~S} \rightarrow 2 \mathrm{AgSbS}_{2}\left(E_{\mathrm{g}}=1.73 \mathrm{eV}\right),
\end{aligned}
$$

etc., where the $\mathrm{CuS}$ [42], $\mathrm{SnS}$ [37], $\mathrm{PbS}$ [38], $\mathrm{Bi}_{2} \mathrm{~S}_{3}$ [39] $\mathrm{Ag}_{2} \mathrm{~S}$ [81] $\mathrm{Sb}_{2} \mathrm{~S}_{3}$ [48] films are produced by chemical bath deposition. In the case of $\mathrm{SnS}$ and $\mathrm{SnS}_{2}$, it has been reported that by controlling the bath composition and temperature either of the composition may be obtained [82]. Further, new materials may also be created by combining chemical deposition technique with thermal evaporation or sputtering of metals, for example, $\mathrm{Sb}_{2} \mathrm{~S}_{3}+3 \mathrm{CuS}+3 \mathrm{Cu} \rightarrow 2 \mathrm{Cu}_{3} \mathrm{SbS}_{3}$, etc. We consider that creation of new thin-film materials by the above approaches is vital for the further advancement of the chemical bath deposition technique and integration of the films produced in this way into solar energy technologies.

\subsection{Toxicity considerations}

The chemical deposition technique involves the use of dilute solutions of compounds involved in the reaction. This offers minimum toxicity and occupational hazards since the vapor phase of the reactants are avoided. It is well known that toxicity hazards associated with lead, cadmium, mercury, selenium, etc, are severe when inhaled [83]. An analysis on the toxicity hazard in the production of chemically deposited PbS thin films is given in Ref. [84] where it was established that the chemical bath technique does not entail the usual health hazards associated with lead pollution. Further, the unreacted ions can be precipitated in the bath as sulfides or selenides and the solid can be separated and stored for use as discussed above in Section 3.8 or recycled to produce starting material. The formation of multinary compounds by interfacial diffusion and recrystallization in multilayer films as given above can be considered as an environmentally sound process since very few effluents are produced. Overall, the-large area capability and the ease of scaling up with complete control of material handling in solid or liquid phase offers perspective toward the industrial production of coatings and devices by the chemical bath deposition technique.

\section{Conclusions}

In this paper we presented a perspective on the chemically deposited thin films: the deposition technique, post-deposition processing, the use of precipitate and an overview of the applications related to solar energy utilization. We consider that this research area offers immense possibilities in creating new materials by annealing multilayer film or combining chemically deposited films with vacuum-deposited metallic films. Future research efforts may be directed in this direction. 


\section{Acknowledgements}

The authors are grateful to Leticia Baños of the Instituto de Investigaciones en Materials, UNAM, for recording the XRD patterns. Financial support for this work was received from CONACYT, México through 1816-E9211 and from DGAPAUNAM through IN-502594 and IN-501495. One of us (V.M.G) is grateful to the Universidad Autonoma de Zacatecas for financial support.

\section{References}

[1] O. Houser, E. Beisalski, Chem-Ztg. 34 (1910) 1079.

[2] K.L. Chopra, R.C. Kainthla, D.K. Pandya, A.P. Thakoor, in: G. Hass, M.H. Francombe, J.L. Vossen (Eds.), Physics of Thin Films, vol. 12, Academic Press, New York, 1982, p. 201.

[3] C.D. Lokhande, Mater. Chem. Phys. 27 (1991) 1-43.

[4] I. Grozdanov, Semicond. Sci. Technol. 9 (1994) 1234.

[5] L. Huang, P.K. Nair, M.T.S. Nair, R.A. Zingaro, E.A. Meyers, J. Electrochem. Soc. 141 (1994) 2536.

[6] P.K. Nair, L. Huang, M.T.S. Nair, Hailin Hu, E.A. Meyers, R.A. Zingaro, J. Mater. Res. 12, 1997, (in Press).

[7] D.E. Bode, in: G. Hass, R.E. Thun (Eds.), Physics of Thin Films, vol. 3, Academic Press, New York, 1966, p. 275.

[8] A.G. Stanley, Cadmium Sulfide Solar Cells, in: R. Wolf (Ed.), Applied Solid State Sciences, vol. 5, Academic Press, New York, 1975, p. 251.

[9] S.V. Svechnikov, E.B. Kaganovich, Thin Solid Films 66 (1980) 41.

[10] G.B. Reddy, V. Dutta, D.K. Pandya, K. L Chopra, Sol. Energy Mater. 15 (1987) 383; 15 (1987) 153.

[11] C. Estrada-Gasca, G. Alvarez-García, R.E. Cabanillas, P.K. Nair, Renewable Energy 2 (1992) 477; J. Phys. D 25 (1992) 1142.

[12] P.K. Nair, M.T.S. Nair, A. Fernández, M. Ocampo, J. Phys. D 22 (1989) 829.

[13] C. Estrada-Gasca, G. Alvarez-García, P.K. Nair, J. Phys. D 26 (1993) 1304.

[14] R.A. Boudreau, R.D. Rauh, J. Elctrochem. Soc. 130 (1983) 513.

[15] M.E. Rincón, M. Sánchez, A. Olea, I. Ayala, P.K. Nair, Photoelectrochemical behavior of thin CdS, coupled CdS/CdSe semiconductor thin films, Solar Energy Mater. Solar Cells (1997), These proceedings.

[16] O. Savadogo, Chemically and electrochemically deposited thin films for solar energy materials, Solar Energy Mater. Solar Cells (1997) These proceedings.

[17] Bluent Basol, Vijay Kapur, IEEE Trans. Electron Dev. 37 (1990) 418.

[18] T.R. Tuttle, M.A. Contreras, J.S. Ward, A.L. Tennant, K.R. Ramanathan, J. Keane, R. Noufi, in: C.M. Lampert et al. (Ed.), Proc. SPIE, vol. 2531, SPIE, Bellingham, 1995, p. 194.

[19] M.A. Mickelsen, W.S. Chen, Appl. Phys. Lett. 36 (1980) 371.

[20] A. Rothwarf, Proc. 16th IEEE Photovoltaic Specialists Conf., San Diego, CA, IEEE, New York, 1982, p. 791.

[21] B.M. Basol, V.K. Kapur, A. Halani, C. Leidholm, in: K.A. Summers (Ed.), Annual Report, Photovoltaic Subcontract Program FY 1991, Golden, NREL, p. 50.

[22] O. Savadogo, K.C. Mandal, Appl. Phys. Lett. 63 (1993) 12.

[23] O. Savadogo, K.C. Mandal, J. Electrochem. Soc. 141 (1994) 2871.

[24] O. Savodogo, K.C. Mandal, J. Phys. D 27 (1994) 1070.

[25] P.K. Nair, V.M. García, A.B. Hernandez, M.T.S. Nair, J. Phys. D 24 (1991) 1466.

[26] P.K. Nair, O. Gomezdaza, M.T.S. Nair, Adv. Mater. Opt. Electron. 1 (1992) 139.

[27] P.K. Nair, M.T.S. Nair, O. Gomezdaza, R.A. Zingaro, J. Electrochem. Soc. 140 (1993) 1085.

[28] J. Basset, R.C. Denney, G.H. Jeffery, J. Mendham, in: Vogel's Textbook of Quantitaive Inorganic Analysis, 4th ed., ELBS/Longman, London, 1978, p. 25. 
[29] D.R. Lide, (Editor-in-Chief), CRC Handbook of Chemistry and Physics 76th Ed., CRC Press, Boca Raton, 1995-96, pp. 8-58.

[30] J. Bjerrum, B.V. Agarwala, S. Refn., Acta Chem. Scand. A 35 (1981) 685.

[31] N.R. Pavaskar, C.A. Menezes, A.B.P. Sinha, J. Electrochem. Soc. 124 (1977) 743.

[32] M.T.S. Nair, P.K. Nair, R.A. Zingaro, E.A. Meyers, J. Appl. Phys. 75 (1994) 1557.

[33] M.T.S. Nair, P.K. Nair, H.M.K.K. Pathirana, R.A. Zingaro, E.A. Meyers, J. Electrochem. Soc. 140 (1993) 2987.

[34] V.M. García, M.T.S. Nair, P.K. Nair, R.A. Zingaro, Semicond. Sci. Technol. 11 (1996) 427.

[35] P.K. Nair, M.T.S. Nair, Semicond. Sci. Technol. 7 (1992) 239.

[36] C.A. Estrada, P.K. Nair, M.T.S. Nair, R.A. Zingaro, E.A. Meyers, J. Electrochem. Soc. 141 (1994) 802.

[37] M.T.S. Nair, P.K. Nair, Semicond. Sci. Technol. 6 (1991) 132.

[38] P.K. Nair, M. Ocampo, A. Fernandez, M.T.S. Nair, Sol. Energy Mater. 20 (1990) 235; V.M. García, M.T.S. Nair, P.K. Nair, Sol. Energy Mater. 23 (1991) 47.

[39] M.T.S. Nair, P.K. Nair, Semicond. Sci. Technol. 5 (1990) 1225.

[40] P.K. Nair, J. Campos, A. Sánchez, L. Baños, M.T.S. Nair, Semicond. Sci. Technol. 6 (1991) 393.

[41] V.M. García, M.T.S. Nair, P.K. Nair, R.A. Zingaro, Semicond. Sci. Technol. 12 (1997) (May issue), in press.

[42] P.K. Nair, V.M. García, A.M. Fernández, H.S. Ruiz, M.T.S. Nair, J. Phys. D 24 (1991) 441.

[43] O. Madelung, in: Semiconductors other than Group IV elements, III-V compounds, Springer, Berlin, 1992.

[44] M. Moskovits, in: G. Soles (Ed.), Chemical Physics of Atomic and Molecular Clusters, North Holland, Amsterdam, 1990, p. 397.

[45] For example, M.N. Rudden, J. Wilson, Elements of Solid State Physics, Wiley, Chichester, 1980, p. 59.

[46] L. Brus, J. Chem. Phys. 90 (1986) 2555.

[47] G. Hodes, A.A. Yaron, F. Decker, P. Motisuke, Phys. Rev. B 36 (1987) 4215.

[48] K.C. Mandal, O. Savadogo, Sol. Energy Mater. Sol. Cells 26 (1992) 117.

[49] K. Okamoto, S. Kawai, Jpn. J. Appl. Phys. 12 (1973) 1130; J.J. Loferski, J. Schewchun, S.D. Mittleman, E.A. DeMeo, R. Arnott, H.L. Hwang, R. Beauliew, G. Chapman, Sol. Energy Mater. 1 (1979) 157.

[50] H.S. Randhawa, R.F. Bunshah, D.G. Brock, B.M. Basol, O.M. Staffsudd, Sol. Energy Mater. 6 (1982) 445.

[51] M.T.S. Nair, P.K. Nair, Semicond. Sci. Technol. 4 (1989) 191.

[52] J.W. Orton, B.J. Goldsmith, J.A. Chapman, M.J. Powell, J. Appl. Phys. 53 (1982) 1602.

[53] M.V. García-Cuenca, J.L. Morenza, J.M. Cordina, J. Phys. D 20 (1987) 951.

[54] R.L. Call, N.K. Jaber, K. Seshan, J.R. Whyte, Sol. Energy Mater. 2 (1980) 373.

[55] P.K. Nair, M.T.S. Nair, R.A. Zingaro, E.A. Meyers, Thin Solid Films 239 (1994) 85.

[56] M.T.S. Nair, P.K. Nair, H.M.K.K. Pathirana, R.A. Zingaro, E.A. Meyers, J. Electrochem. Soc. 140 (1993) 2987.

[57] P.J. George, A. Sánchez, P.K. Nair, M.T.S. Nair, Appl. Phys. Lett. 66 (1995) 3624.

[58] P.J. George, A. Sánchez-Juarez, P.K. Nair, Semicond. Sci. Technol. 11 (1996) 1090.

[59] V.M. García, P.J. George, M.T.S. Nair, P.K. Nair, J. Electrochem. Soc. 143 (1996) 2892.

[60] M. Savelli, J. Bougnot, in: B.O. Seraphin (Ed.), Solar Energy Conversion and Topics in Applied Physics, vol. 31, Springer, Berlin, 1979, p. 213.

[61] C.A. Estrada, R.A. Zingaro, E.A. Meyers, P.K. Nair, M.T.S. Nair, Thin Solid Films 247 (1994) 208.

[62] P.K. Nair, M.T.S. Nair, H.M.K.K. Pathirana, R.A. Zingaro, E.A. Meyers, J. Electrochem. Soc. 140 (1993) 754.

[63] K.L. Chopra, S.R. Das, in: Thin Film Solar Cells, Plenum, New York, 1982, p. 233.

[64] H. Matsumoto, K. Kuribayashi, H. Uda, Y. Komatsu, A. Nakamoto, S. Ikegami, Sol. Cells 11 (1984) 367.

[65] O. Gomezdaza, V.M. García, M.T.S. Nair, P.K. Nair, Appl. Phys. Lett. 68 (1996) 1987-1989.

[66] P.K. Nair, M.T.S. Nair, J. Campos, L.E. Sansores, Sol. Cells 22 (1987) 213.

[67] M.T.S. Nair, P.K. Nair, J. Campos, Thin Solid Films 161 (1988) 21.

[68] H. Hu, J. Campos, P.K. Nair, J. Mater. Res. 11 (1996) 739.

[69] M.E. Rincon, P.K. Nair, Semicond. Sci. Technol. 12 (1997) at Press. 
[70] M.T.S. Nair, P.K. Nair, Semicond. Sci. Technol. 4 (1989) 599.

[71] H. Hu, P.K. Nair, Surface Coating Technol. 81 (1996) 183.

[72] P.K. Nair, M.T.S. Nair, Semicond. Sci. Technol. 4 (1989) 807.

[73] M.T.S. Nair, P.K. Nair, J. Phys. D 24 (1991) 450.

[74] M.T.S. Nair, G. Alvarez-Garcia, C. Estrada-Gasca, P.K. Nair, J. Electrochem. Soc. 140 (1993) 212.

[75] A.M. Fernandez, M.T.S. Nair, P.K. Nair, Mater. Manufr. Process 8 (1993) 535.

[76] A.M. Fernandez, P.K. Nair, Thin Solid Films 204 (1991) 459.

[77] Vitro Vidrio Plano-Industria Quimica M, S.A. de C.V., Tlaxcala-Puebla, Tlaxcala C.P.90780 AP 942 México.

[78] P.K. Nair, M.T.S. Nair, J. Phys. D 24 (1991) 83.

[79] V.M. Garcia, M.T.S. Nair, P.K. Nair, Solar Energy Mater. 23 (1991) 47.

[80] B. Window, Solar Energy 31 (1983) 159.

[81] A.J. Varkey, Solar Energy Mater. 21 (1991) 291.

[82] R.D. Engelken, H.E. McCloud, C. Lee, M. Slayton, A. Ghreishi, J. Electrochem. Soc. 134 (1987) 2696.

[83] N.I. Sax, Dangerous properties of Industrial Materials, 6th ed., Van Nostrand, Reinhold, New York, 1984, p. 612, 1693, 1751, 2390.

[84] P.K. Nair, M.T.S. Nair, J. Phys. D 23 (1990) 150. 